\title{
The Problem of Identifying Mudan 牡丹 and the Tree Peony in Early China
}

\author{
Teruyuki Kubo
}

\begin{abstract}
The tree peony is a flowering plant found in China, and well-known in Britain. Its root cortex is often used in Chinese traditional prescriptions, such as Dahuang mudan tang, Liuwei dihuang wan, and Jiawei shaoyao san. In contemporary Chinese, the tree peony is called 'mudan', and although its beauty was largely ignored until the Kaiyuan era (713-41 CE), a drug of the same name is mentioned in medical texts of the Eastern Han period (25-220 CE). The early authoritative materia medica, Хіпxiи bencao (659 CE), also describes a plant called 'mudan', but it is different from the tree peony in form. Curiously, although the tree peony is not considered to be native to Japan, it is described as a specialty plant in the early Japanese gazetteer, Izumonokuni Fudoki (733 CE).

This study demonstrates that in early texts 'mudan' referred to a different plant from the tree peony, and that 'mudan' had two remarkable aliases, 'bailiangjin' in China and 'yamatachihana' in Japan. Today, both aliases are used to refer to Ardisia species. Furthermore, I will demonstrate that the Xinxiu bencao's description of the mudan closely matches that of the Ardisia, especially the A. japonica species. My investigations therefore suggest that early prescriptions may have used the Ardisia species, not the tree peony. This raises further questions: when and how did the tree peony come to replace the Ardisia? This paper presents the most likely progression of this transition by tracing the expansion of cultivation of mudan for ornamental purposes.
\end{abstract}

\section{Keywords}

tree peony, Ardisia, Bencao, China, Japan, mudan, mōgtan, yamatachibana, botan

\section{The problem of identification}

The tree peony, called mudan (or moutan, 牡丹) in Chinese, is a flowering plant found in China and now widely cultivated in East Asia as well as Britain, Europe and the United States. Though the herbaceous peony (shaoyao 药藥) figured prominently in early Chinese literature, the mudan was largely ignored before the Tang dynasty (618-907 CE) except for its medicinal applications. In the inner court of the Shengtang 盛唐 (High Tang) era (713-765 CE), the mudan was praised by the emperor Xuanzong 玄宗 (reigned 712-756 CE), and became fashionable in the Zhongtang 中唐 era (766-835 CE). During 
this period, many Chinese extolled the tree peony as 'the king of flowers' (Huawang 花王). Appreciation of the flower continued throughout the turbulent period of the Five Dynasties (Wudai shiguo 五代十國), and lasted until around 1127 CE, when the Northern Song dynasty fell. Today, as some Chinese attempt to select a national flower, the peony may yet emerge as the most likely candidate.

In East Asia, tree peonies are used as ornamental plants and in traditional medicine. Some traditional Chinese prescriptions, such as Dahuang mudanpi tang 大黄牡丹皮湯, Liuwei dihuang wan 六味地黄丸, Jiawei shaoyao san 加 味逍遙散, and Guizhi fuling wan 桂枝获苓丸 contain root cortex of tree peonies. E. Karia 狩谷棭齊 (1775-1835 CE), however, has challenged the identification of the mudan:

The medicinal mudan must be the same plant that is called the yabutachibana 藪 立花 in the west of the empire [of Japan], and is called yabukoji i 藪柑子 in the east... You must use this [herb]. It is wrong that people today use tree peonies instead of the mudan's cortex in prescriptions. ${ }^{1}$

Regretably, this opinion has been almost completely ignored until now. Nakao and Kimura once made mention of Karia's idea but rejected it. ${ }^{2}$ However, re-examination of the cultural history of the tree peony in China provides several pieces of evidence that support Karia's opinion.

Before beginning this discussion, it is worth defining some key terms related to the tree peony. Chinese pronunciation changed considerably from the SuiTang dynasties to the Song-Yuan-Ming dynasties: ‘牡丹' conventionally represents 'môgtan', in early texts (from the Han dyansty to the Early Tang era), while later it represents 'mudan'. ${ }^{3}$ For clarity, in this paper I will follow this division, although, strictly speaking, there have been other variations on pronunciation over time. The classification system of the genus Paeonia is also controversial. In the 1990s, Hong Tao 洪濤 and G. Osti promoted several subspecies and varieties to the rank of species, and re-constructed the classification of the

${ }^{1}$ Kariya 1981 [1827], p. 446. 詳蘇敬所說, 本草告丹, 即皇國西俗所呼藪立花, 東俗所呼 藪柑子也.' Translation by Teruyuki KUBO.

2 Nakao and Kimura 1929, pp. 15-19. ‘牡丹] 郎ち野生種にして觀賞用に供せざるもの とす。故に是を藥用に供する眞品なりと爲す。「今俗用此に異る」と謂ふは觀賞用の牡 丹を當時藥用に供したるが故に「俗用此に異る」と言ふのみ。故に宋、明を經て未だ此 の註に對して疑惑を懷く人非ず、箋注倭名類聚抄の説く所は正しからず、好みて異説を 述ぶるに似たり’

${ }^{3}$ Karlgren 1972 [1957], pp. 60, 274. (Karlgren defined 'ô' as like French 'beau.') 'Although there are several reconstructed pronunciation systems by later scholars who have advanced the system of Karlgren, the reconstruction is still in progress. For the meantime, this paper, therefore, follows the Karlgren's system to represent the early Chinese pronunciation. 
tree peony. ${ }^{4}$ However, in 1997, Josef J. Halda re-examined the same specimens and raised some objections. ${ }^{5}$ As a result, several major species and most traditional cultivars are referred to by a single botanical name, Paeonia suffruticosa. In this paper, the classification system and scientific names of peonies will follow the Halda's classification, ${ }^{6}$ and the term 'tree peony' will refer only to the P. suffruticosa.

According to Halda, the wild P. suffruticosa grows in Anhui, Gansu, Hunan, Shanxi, Sichuan, and Yunnan. ${ }^{7}$ His description of the morphological features of subspecies suffruticosa as a typical example) is as follows:

A shrub up to $2 \mathrm{~m}(6.5 \mathrm{ft}$.) tall, with glabrous branches and bipinnate leaves, usually with nine or sometimes more leaflets, ovate to broadly ovate, terminal leaflets usually deeply three-lobed, often with a few additional shallow lobes. Very rarely entire, tips of lobes acute, rachis and petiole more or less glabrous. Flowers single or double; petals white, pink, red, purple, or lilac, immaculate (rarely with a reddish-purple basal blotch). Flowers from April to May.

Distribution: China, in provinces of Shaanxi, and western Hubei, and in south eastern Tibet, growing in thickets and open woodland at altitudes from 800 to $1500 \mathrm{~m}$ (2640 to $4950 \mathrm{ft}.)^{7}$

\section{Aim of this paper}

Since the identification of plant ingredients in traditional Chinese drugs was not based on the scientific specimens established by modern taxonomy, there have always been difficulties and limitations to investigating the identities of drug ingredients. ${ }^{8}$ Shaoyao 芶藥, for an example, is the Chinese name for the herbaceous peony. This term first appeared in poems written before the sixth century BCE (Shi jing 詩經), and an eminent Confucian scholar in the Eastern Han dynasty, Zheng Xuan 鄭玄 (127-200 CE), commented: 'shaoyao is a certain fragrant plant'. 'However, the herbaceous peony is not fragrant, which has led Lu Ji 陸璣 to question which plant 'shaoyao' actually referred to.

${ }^{4}$ Hong Tao et al. 1992, pp. 223-234; Hong Tao and G. L. Osti 1994, pp.237-240; Hong Tao and Dai Zhenlun 1997, pp. 1-5; Osti, G. 1999.

5 Halda and Waddick 2004, p. 24.

${ }^{6}$ Halda and Waddick pp. 141-71.

7 Halda and Waddick p. 151.

${ }^{8}$ Drugs ingredients in Shôsôin 正倉院 of Japan can be considered as a special case. About thirty drug ingredients which are listed in the catalogue 'Shuju Yakuchô 種々藥帳' have been preserved for more than 1300 years with the catalogue. Recent scientists have investigated them (Asahina 1955).

9 Ruan Yuan (ed.) 1980 [1816], p. 346. 詩經, 鄭風, 野有蔓草. ‘句藥, 香草.' In early China, Shao 苟 of shaoyao was actually written as shao 勺 or $x i$ 夕, without the head radical of grass \# 
He wrote: 'the current shaoyao used as medicinal plant does not possess any fragrance. [That plant] must be a different plant but its exact nature remains unknown'. ${ }^{10}$ The identity of that shaoyao remains unconfirmed, despite further investigations by Zheng Qiao 鄭樵, Yao Jiheng 姚際恆 and others. ${ }^{11}$ Furthermore, one plant name could refer to two or more plants in different regions, and such regional differences apply for the mogtan as well. The intention of this paper is twofold: to demonstrate the differences between the môgtan appearing in old Chinese texts and the tree peony, and secondly, to investigate which plants 'môgtan' could have referred to.

\section{Môgtan in the early Chinese texts}

This chapter outlines the history of the môgtan in China, and compares it to that of the tree peony. Joseph Needham has investigated the first appearance of the word môgtan. He cites a fragment from Jinizi 計倪子 (or Fanzi Ji Ran 范子計然), noting:

The name môgtan occurs for the first time in a text which we generally attribute to the forth century BCE, though it must have Han interpolations, the Jinizi book. ${ }^{12}$

As he mentioned, it is doubtful that all words in Jinizi existed around 400 BCE.

From the Han to the Wei Jin dynasty (25-420 CE): the early descriptions

The word 'môgtan' 牡丹 appeared in Eastern Han (25-220 CE) in the excavated medical bamboo slips found at present-day Wuwei in Gansu province, namely the Wuwei Handai yijian 武威漢代醫簡 (Wuwei Medical Bamboo Slips of the Han Dynasty), ${ }^{13}$ as well as in the texts, Shennong bencao jing 神農 本草經 (Divine Farmer's Canon of Materia Medica) and Jinkui yaolüe 金貴要略

(Shao 勺 was pronounced like disok which is similar to $d z i a ̆ k$, the old pronunciation of $x i$ 夕, according to Karlgren 1980, pp. 209, 288.)

${ }^{10}$ I bid. p. 346. ‘今藥草勺藥無香氣, 非是也... (古藥方中牡丹皮) 宜用之. 今人以木药根皮 為牡丹皮者誤. 未審今何草.

${ }^{11}$ Zheng Qiao 1987 [1161], p. 868; Yao Jiheng 1958 [c. 1709], pp. 112-13. '又謂, “藥, 香草也.”亦謬. 勺藥即今牡丹, 古名勺藥. 自唐玄宗始得木藥于宮中, 因呼牡丹. 詳見予庸 言錄. 其花香, 根葉不香, 何得混云香草乎... 又鄭即河南地. 今河南牡丹甚多, 蓋古時已然, 故詩人所咏及之焉.'; Mizukami 1977, pp. 686-703.

12 Needham 1986, p. 396.

13 Gangsu Bowuguan and Wuxian Wenhuaguan (eds) 1975, p. 2. 
(Synopsis of the Golden Chamber).${ }^{14}$ Remarkably, môgtan was not mentioned in mainstream Chinese literature in this period, which confirms that the plant was used mainly for medical purposes. In Shennong bencao jing, môgtan was described as follows:

Môgtan, is also called lujiu or 鹿韭 and shugu 鼠姑, it has a piquant taste; [it has a] cold [attribute] and is nonpoisonous. The main curable symptoms are Zhongfeng 中風 with shiver and fever; Chizongjing (疶疭痤, infantile convulsion); epilepsy induced by terror; evil qi. [It] eliminates a hard lump, and stagnated blood remaining (liushe 留舎) in the stomach and intestine. [Again, it can] calm the five areas of the body; and it can cure external carbuncles. It grows in mountain valleys. ${ }^{15}$

In the Wei Jin 魏晉 dynasties, môgtan appeared in two medical texts, Wu Pu bencao 吳普本草 (Wu Pu's bencao) and Mingyi bielu 名醫別錄 (Separate Records of Eminent Physicians). In Wu Pu bencao, môgtan was described as follows:

Shennong 神農 and Qibo 岐伯 affirm that its sapidity is acrid. Mr Ji (季) considers it slightly algogenic (cooling). Leigong 雷公 and Tongjun 桐君 say that the sapidity is acerbic with no dangerous active principle, but (the) Huangdi 黃帝 (book) says that though [it is] acerbic it does have [has] a dangerous active principle. The leaves are like those of the peng 蓬 set opposite each other mutually. The colour (of the flower) is yellow. The root is the thickness of a finger, and black, this is where the dangerous active principle resides. (The fruits and seeds) should be picked between the second and the eighth months, and when dried in the sun can be eaten. They lighten the body and promote longevity. ${ }^{16}$

The character 'peng'蓬 does not refer to a certain plant, but is often associated with species in both the Asteraceae and Chenopodiaceae families. ${ }^{17}$ It is therefore difficult to ascertain which plant Wu Pu actually picked out. Moreover, the differences in descriptions of sapidity and toxicity imply that 'môgtan' does not refer to a specified plant or group of plants. Perhaps, the môgtan could have referred to two or more different plants.

In Mingyi bielu, which contains the teachings of a number of eminent physicians before the end of the fifth century, môgtan was described as follows:

14 Kubo et al. 1979 , pp. 155-56.

15 Ma Jixing, 1995, p. 239-40. ‘牡丹. 一名鹿非, 一名鼠姑. 味辛, 寒, 無毒. 治寒熱, 中風,

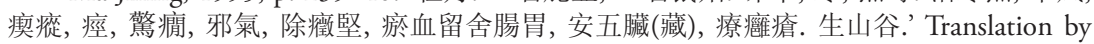
T. Kubo.

16 Shang Zhijun 2005, p. 63. ‘牡丹, 神農, 歧伯辛. 季氏小寒. 雷公, 桐君苦, 無毒. 黄帝苦, 有毒. 葉如蓬相值, 黄色. 根如指, 黑. 中有毒核. 二月採, 八月採. 日乾可食之. 輕身益壽. Translation by Needham 1986, p. 397, but 'Mr Li' has been replaced with Ji (季) in order to follow the source.

${ }_{17}$ Kano, T. Kubo and Yoshino 2003, pp. 133-34. 
[Môgtan has a] bitter taste and [a] slightly cold [attribute]. [It] cures epidemic disease, headache with fever caused by [external factors], the wulao 五勞 (five strains), laoqi 勞氣( (hyperhidrosis), headache, lumbar pain, tetanus neonatorum, and epilepsy. They grow in Bajun's 巴郡 mountain valleys and in Hanzhong 漢中. [Its roots] should be gathered in February and August and should be dried in the shade. ${ }^{18}$

As shown above, the môgtan's distributions have been recorded. Bajun 巴郡, the eastern Sichuan province, lies across the Dabashan 大巴山 mountains from Hanzhong 漢中, located at the southwest end of the Shaanxi province. Both areas are close to the places where wild tree peonies are found (Figure 1).

First, Zhang Yi 張揖 says in Guangya 廣雅 (Expanded Erya 爾雅), his dictionary, 'baishu 白荙, [this is] môgtan 牡丹'. ${ }^{19}$ 'Baishu' is now thought to refer to the Atractylodes macrocephala Koidz., a plant very different from the tree peony. There is similar confusion in early Chinese dictionaries, probably because their editors were not familiar with the plants.

Secondly, a fragment of Gujin zhu 古今注, records that 'there are two kinds of shaoyao: herbaceous and woody. The latter has larger, more deeply coloured flowers and is commonly, but wrongly, called môgtan' ${ }^{20}$ While the most recent edition of Gujin zhu does not include that fragment, it was cited by Su Song 蘇頌 et al. in the Song dynasty.

Wang Niansun 王念孫, a Chinese scholar of Qianlong’s 乾隆 reign (17361795), investigated early texts concerning môgtan. He wrote that 'baishu' 白术 was an alias of shaoyao in both Wu Pu bencao 吳普本草 and Mingyi bielu 名 醫別錄, and that 'baishu' was also an alias of môgtan, in Guangya. In addition, he cited the fragment quoted above in the Gujin zhu. He concluded that the name 'baishu' simply referred to white root core of any peony, and that 'môgtan' referred to red cortex of peony roots. ${ }^{21}$ However, baishu itself refers to

18 Tang Shenwei 1992 [1108] vol. 2: 554; Tang Shenwei 1970 [1108], pp. 254-55; Tang Shenwei 1957 [1108], p. 257. '(牡丹) 苦, 微寒, 無毒. 除時氣, 頭痛, 客熱, 五勞, 勞氣, 頭腰痛, 風噤, 癲疾. 生巴郡山谷及漢中.二月八月採根陰乾. Translation by T. Kubo. According to Suwen 素問, Wulao was explained as following, “五勞所傷, 久視傷血, 久卧傷氣, 久坐傷肉, 久 立傷骨, 久行傷筋”. (Wang Bin 1963, p. 154) These are symptoms associated with physical fatigue. Chao Yuanfang 巢元方 et al. raised psychic fatigue as '志勞, 思勞, 心勞, 憂勞, 瘦 勞'(Chao Yuanfang et al. 1996 [610], pp. 87-88). Zhang Zhongjing 張仲景 remarked about laoqi 勞氣, 'a sweating after meals and also usually sweating in sleeping is laoqi 勞氣' (Guo and Okada (eds.) 1999, p. 201. 水氣病脈證并治第十四, 黃耆苟桂苦酒湯方, “食已汗出, 又常暮盗 汗出者, 此勞氣也.').

19 Wang Niansun 2004 [1796], p. 320. ‘白茂’, ‘牡丹.’

20 Tang Shenwei 1992 [1108] vol. 2: 554; Tang Shenwei 1970 [1108], p. 254; Tang Shenwei 1957 [1108], p. 257. “崔豹古今注. 苟藥有二種, 草苟藥, 木苟藥. 木者花大而色深, 俗呼為牡 丹, 非也.' Translation by Needham, 1986, p. 397.

21 Wang Niansun 2004 [1796], p. 320. 則古方俗相傳以木苟藥為牡丹, 故本草以白术為苟 藥, 而廣雅又以為牡丹. 異名蓋其通稱已久. 不自崔豹時始矣. 陶注本草云, 药藥今出白山, 蔣 


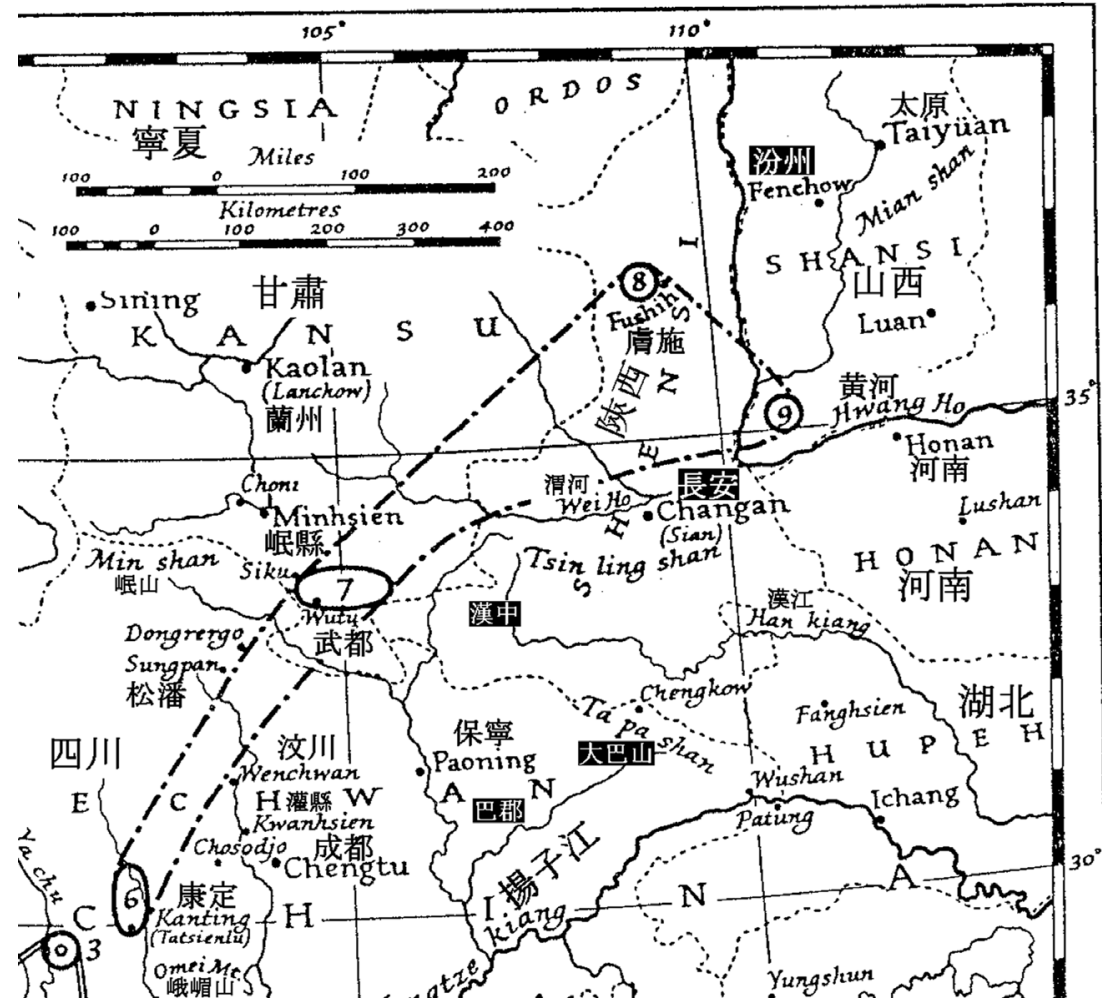

Fig. 1. Map of Western China and adjacent regions, showing distribution of paeonia sect. Moutan: 6-7. P. Suffruticosa: 8-9. P. Suffruticosa var. Spontane 22

another herbal plant. His conclusion suggests mudan is distinguished by its red colour from shaoyao, regardless of whether a woody or herbaceous peony, but Tao said 'mudan ... the red one is better', which implies mudan can possibly allude to other coloured roots.

Gujin zhu was originally written by Cui Bao 崔豹 in the Jin 晉 dynasty. However, during the period of the Five Dynasties, another scholar, Ma Gao 馬縞, added a commentary which has been merged with the original text.

山, 茅山最好, 白而長大. 唐本草注云, 牡丹, 劍南所出者根似芳藥, 肉白皮丹. 然則荷藥牡丹 之共稱白术, 皆以白得名. 蓋以其皮丹則謂之牡丹, 以其肉白則謂之白术矣.'

22 Stern 1946, p. 18. [Chinese names have been translated into English phonetically. I added Chinese names each side of the English name in the figure 1.] 
The current text of the Gujin zhu is thought to have been assembled from collected fragments. ${ }^{23}$ This text includes a story in which Niu Heng 牛亨 asked Dong Zhongshu 董仲舒 about shaoyao. In the Tang dynasty, Ouyang Xun 歐陽詢 et al. cited part of the same story. ${ }^{24}$ Thus the story is probably derived from Cui's words, because the surviving fragment appeared before $\mathrm{Ma}$ added his comments, while the fragment cited by Su Song et al., is likely to be Ma's version of story rather than Cui's own.

\section{From the Southern dynasties to the Sui dynasty (420-618 CE)}

In the Southern dynasties (Nanchao 南朝), Xie Lingyun 謝靈運 (385-433 CE) and Tao Hongjing 陶弘景 (456-536 CE) both mention môgtan. In fragments from Xie’s work, Xie kangle ji 謝康樂集, môgtan is described as follows:

(a) Xie kangle ji 謝康樂集 writes that môgtan grew extensively among bamboos and waterside in Youyang zazu 酉陽雜組 (c. $860 \mathrm{CE}) .^{25}$

(b) You Mingshan zhi 遊名山志 writes that môgtan grew extensively on the mountain Quanshan 泉山 in Taiping yulan 太平御覽 (983 CE). ${ }^{26}$

(c) Xie Lingyun writes that môgtan grew extensively among bamboos and/or waterside in Yongjia 永嘉 in Luoyang mudan ji 洛陽牡丹記 (c. 1034 CE). ${ }^{27}$

Xie was the administrator of the Yongjia region (Yongjia Taishou 永嘉太守) from 422 to 424 . During this period, he recorded his observations of herbs in his Travel Record in Famous Mountains (You Mingshan zhi 遊名山志). ${ }^{28}$ According to Xie, môgtan grew among bamboo on the waterside in Quanshan and Yongjia. Yongjia is the former name of Wenzhou 溫州; and Quanshan is probably the mountain now called Daluoshan 大羅山, which is located in

${ }^{23}$ Yu Jiaxi 1958, pp. 853-63. ‘四庫全書)提要第見(馬)縞書通體作大字, 並無雙行小注. 皆謂末嘗添注釋義.

${ }^{24}$ Cui Bao 1998 [fl. 290-306], p. 16. ‘問答釋義... 牛亨問曰, 將離開相別, 贈以苟藥, 何也. [董仲舒] 答, 药藥_一名可離, 故相別以為贈.’; Ouyang Xun 1999 [624], p. 1383. ‘古今注. 药 藥, 一名可離”. Translation by T. Kubo.

25 Duan Chengshi 1981 [c. 860], p. 185. ‘謝康樂集中言, 竹間水際多牡丹.’ Translation by T. Kubo. Zhujian 竹間 may refer to Zhujian 竹澗.

${ }^{26}$ Li Fang et al. 1960 [984], pp. 4392-93. ‘旅名山志曰, 泉山多牡丹.' Translation by T. Kubo.

27 Ouyang Xiu 2001 [ca 1034], 1101. ‘謝靈運言, 永嘉竹間水際多牡丹.' Translation by T. Kubo.

${ }^{28}$ The defective copy remains in Xie kangle ji 謝康樂集 revised by Jiao Hong 焦泣, published in the Ming dynasty (preserved in Naikaku Bunko 內閣文庫 of Japan). Fragments remain in Taiping yulan 太平御覽 etc., e.g. Li Fang et al. 1960 [984], p. 4375. “遊名山志曰, 泉山竹際及 金州多夌 (麥) 門冬.' Translation by T. Kubo. 
Wenzhou. ${ }^{29}$ However, wild tree peonies grow badly in moist soil and hot climates and therefore they hardly grow at all in inhospitable southeastern areas such as Wenzhou. ${ }^{30}$ Similarly, Tao writes that môgtan grew in Dongjian 東間, in the east of China. ${ }^{31}$ As Tao was born during the Southern dynasties and had no access to North China at all, Dongjian is thought to have been located in southeast China. Moreover, Tao notes that the bajitian 巴戟天 looks like môgtan but is smaller, ${ }^{32}$ yet, bajitian is very different in form from the tree peony (Figure 2).

\section{The Chutang 初唐 era (619-712 CE): genuine and counterfeit môgtan}

In 589, Yang Jian 楊堅, who established the Sui 隋 dynasty, re-unified northern and southern China, and in $618 \mathrm{Li}$ Yuan 李淵 took the place of the third Sui emperor and founded the Tang empire. ${ }^{33}$ Under orders from the third Tang emperor, Gaozong 高宗, Su Jing 蘇敬 et al. produced the first governmentapproved compilation of materia medica, Xinxiu bencao 新修本草 (Newly Revised Canon of Materia Medica, completed 659 CE). They not only revised pre-existing materia medica and offered their critical evaluations of earlier commentaries, but also instructed all of the counties in China to send local drug ingredients to them. The editors' main intention was to compare

29 Shi Weile et al. (eds) 2005, p. 1931.

${ }^{30}$ A certain group of tolerant wild peonies grow in Tongling 銅陵, a mountainous district of the southern Anhui 安徽 province. This is the southern limit of the wild peony. Based on the history of the tree peony cultivation in Tongling, those wild peonies seem to be known by local people among the Song, Yuan and Ming dynasties (Chen Ranglian 2004, pp. 1-6). Besides, the cultivation of tree peonies in the Jiangnan region also began during the Zhongtang or Wantang era, according to Bai Juyi's poem.

31 Tang Shenwei 1992 [1108], vol. 2: 554; Tang Shenwei 1970 [1108], pp. 254-55; Tang Shenwei 1957 [1108], p. 257. ‘牡丹 ... 陶隱居云, 今東間亦有.' Translation by T. Kubo.

32 Tang Shenwei 1992 [1108], vol. 2: 163; Tang Shenwei 1970 [1108], p. 166; Tang Shenwei 1957 [1108], p. 165. ‘巴戟天... 陶弘景云, 今亦用建平, 宜都者. 狀如牡丹而細. 外赤內黑, 用 之打去心.’ Translation by T. Kubo.

33 There are stories that Emperor Yang of the Sui dynasty (Sui Yangdi 隋煬帝, reigned 604617) was the first to plant the tree peony in Luoyang and of empress Wu Zetian 武則天 (reigned 690-705) moving the tree peony from Chang'an 長安 to Luoyang 洛陽. However, these are not reliable accounts. (Guo Zhaolin 1997, pp. 6-9.) Wu Zetian was a concubine of the third Tang emperor Gaozong. 

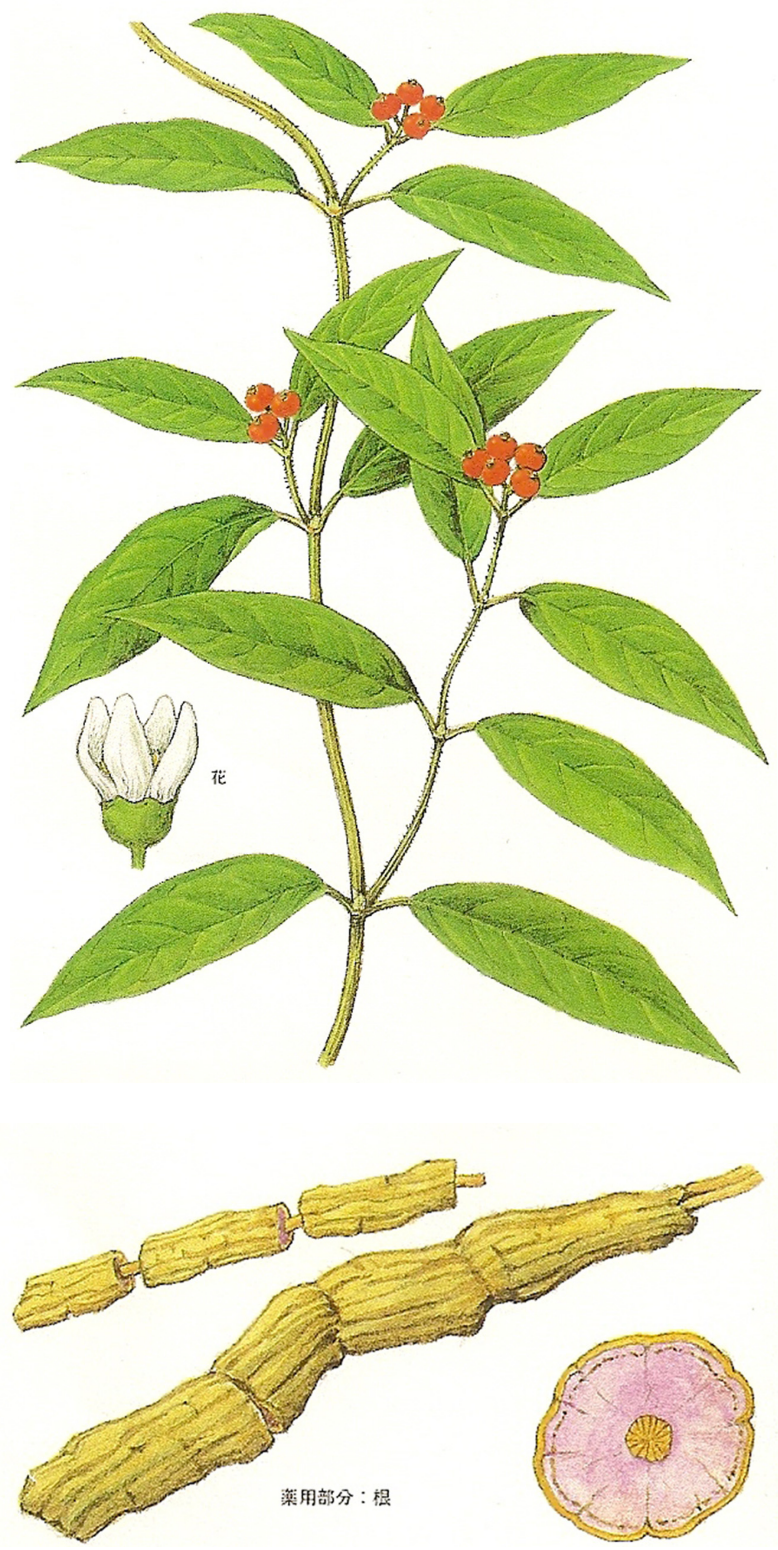

Fig. 2. Bajitian 巴戟天 Morinda officinalis. ${ }^{34}$

${ }^{34}$ Okada and Mitsuhashi, 1988, p. 498. 
ingredients sharing the same name from different regions, in order to separate genuine drug ingredients from counterfeit ones and to eliminate confusion. Previously, Tao had been unable to examine differences between ingredients from the north with those from the south, but thanks to Su Jing et al. this became possible and, therefore, subsequent descriptions are far more precise than those in the earlier bencao (herbal) texts. How, then, was môgtan explained in Xinxiu bencao?

The descriptions of môgtan in Xinxiu bencao is slightly long. As matter of convenience, here the description is divided into two parts. In the first section, môgtan's morphological features and its life cycle are mentioned:

Môgtan from Shanjiang 山江 and Jiannan 劍南 has a miao 苗 looking like yangtao 羊桃 and blooms white flowers in summer; it bears round and green fruits in autumn; the fruits ripen and turn red in winter; [the plant] endures winter without withering (lingdong budiao 凌冬不调). The root looks like a herbaceous peony's and its core is white; [its] cortex is red..$^{35}$

The above quotation states that the root of the mogtan resembles that of the shaoyao (herbaceous peony), but other parts of the descriptions could hardly be of the tree peony, particularly the flower season and seed colour.

For comparison, the table 1 (below) shows the corresponding phrases taken from Tujing bencao 圖經本草 (Illustrated Canon of materia medica, published in the northern Song dynasty). Xinxiu bencao states that it flowers in the summer, but Tujing bencao states the third lunar month, and the tree peony does indeed bloom in the spring. The seeds of the môgtan described in Xinxiu bencao are green in autumn and then turn red in winter, but Tujing bencao states that the seeds are black, which is, again, true of the tree peony. These comparisons show clearly that the word 'môgtan' in the Xinxiu bencao does not refer to the tree peony.

35 Tang Shenwei 1992 [1108] vol. 2: 554; Tang Shenwei 1970 [1108], pp. 254-55; ‘牡丹... 劍南所出者苗似羊桃, 夏生白花, 秋實暑綠, 冬果赤色, 凌冬不调. 根似䓎藥, 肉白皮丹. 山江 (“出江” in the Tang Shenwei 1957 [1108], p. 257), 劒南. 土人謂之牡丹, 亦名百兩金. 京下謂 之吳牡丹者是真也. 今俗用者異於此, 别有臊氣也.' Translation by T. Kubo. Jiannan is the north part of the Bajun, that is mentioned in Mingyi bielu as well. 
Table 1. Comparisons of both the descriptions between the Xinxiu bencao and Tujing bencao

\begin{tabular}{|c|c|c|c|c|c|}
\hline & Distribution & flower & fruit and seed & stem & root \\
\hline $\begin{array}{l}\text { Xinxiu } \\
\text { bencao }^{36}\end{array}$ & 漢中,劍南 & $\begin{array}{l}\text { white } \\
\text { flowers in } \\
\text { summer. }\end{array}$ & $\begin{array}{l}\text { round and } \\
\text { green, fruits in } \\
\text { autumn, the } \\
\text { fruits ripen } \\
\text { and turn red } \\
\text { in winter. }\end{array}$ & $\begin{array}{l}\text { miao resemble } \\
\text { yangtao. } \\
\text { Evergreen }\end{array}$ & $\begin{array}{l}\text { resemble } \\
\text { roots of } \\
\text { shaoyao: } \\
\text { white flesh/ } \\
\text { red cortex. }\end{array}$ \\
\hline $\begin{array}{l}\text { Tujing } \\
\text { bencao }^{37}\end{array}$ & $\begin{array}{l}\text { 丹, 延, 青, } \\
\text { 越, 滁,和州 }\end{array}$ & $\begin{array}{l}\text { yellow, } \\
\text { violet, red } \\
\text { or white } \\
\text { flowers in } \\
\text { the third } \\
\text { lunar } \\
\text { month. each } \\
\text { flower has } 5 \\
\text { or } 6 \text { petals } \\
\text { at most. }\end{array}$ & $\begin{array}{l}\text { black seeds, as } \\
\text { large as those } \\
\text { of the jitouzi } \\
\text { 雞頭子 (fox } \\
\text { nut, or a seed } \\
\text { of Euryale ferox) } \\
\text { are produced } \\
\text { in the fifth } \\
\text { lunar month. }\end{array}$ & $\begin{array}{l}\text { môgtan sprout } \\
\text { on the tops of } \\
\text { lignified stalks } \\
\text { in the second } \\
\text { lunar month. } \\
\text { When their } \\
\text { stems dry up, } \\
\text { they turn grey. }\end{array}$ & $\begin{array}{l}\text { yellowish } \\
\text { white roots: } \\
\text { approx. 5-7 } \\
\text { cun 寸 in } \\
\text { length, the } \\
\text { thickness of } \\
\text { the handle } \\
\text { of a writing } \\
\text { brush. }\end{array}$ \\
\hline
\end{tabular}

It is also explained in the Xinxiu bencao that môgtan resembles yangtao 羊桃 in it's 'miao 苗,' which normally means a 'shoot' or a 'seedling'. However, in Shuben tujing 蜀本圖經, it is pointed out that: 'because the yangtao's miao is long and weak, it is a creeper (蔓生) and cannot become a tree. ${ }^{38}$ Based on the usage of 'miao' here, it could actually refer to a flexible or weak 'stalk' ${ }^{39}$

36 Tang Shenwei 1992 [1108] vol. 2 p. 554; Tang Shenwei 1970 [1108], pp. 254-55; Tang Shenwei 1957 [1108], p. 257. Translation by T. Kubo. “牡丹... 劍南所出者苗似羊桃, 夏生白 花, 秋實暑綠, 冬果赤色, 凌冬不调. 根似苟藥, 肉白皮丹. 出江, 劒南. 土人謂之牡丹, 亦名百 兩金. 京下謂之吳牡丹者是真也. 今俗用者異於此, 别有臊氣也.'

${ }^{37} \mathrm{Ibid}$. '牡丹. 生巴郡山谷及漢中, 今丹, 延, 青, 越, 涂, 和州山中皆有之. 花有黃紫紅白數 色. 此當是山牡丹, 其荎便枯燥黑白色, 二月於梗上生苗葉, 三月開花. 其花葉與人家所種者 相似, 但花止五六葉耳. 五月結子黑色如雞頭子大. 根黃白色, 可五七寸長, 如筆管大.二月八 月採銅刀䢃去骨陰乾用. 此花一名木苟藥, 近世人多貴重, 圃人欲其花之詭異.' Translation by T. Kubo.

38 Tang Shenwei 1992 [1108], vol. 3: 186-87; Tang Shenwei 1970 [1108], p. 305; Tang Shenwei 1957 [1108], p. 273. ‘羊桃... 苗長弱, 即蔓生, 不能為樹.'

39 Instead of miao, chusheng 初生 corresponds to a shoot or a seedling. For instance, renshen 人參 in the Tujing bencao was discribed as “人參... 春生苗, 多於深山中... 初生小者二四寸 許... 苗長一二尺...' Here, chusheng can be considered as a seedling because of its length; miaozhang 苗長 means the height from the ground to the top. (Tang Shenwei 1992 [1108], vol. 2: 35-36; Tang Shenwei 1970 [1108], p. 136; Tang Shenwei 1957 [1108], p. 146). 
'Môgtan', as described in Xinxiu bencao, could, therefore, be presumed to be a creeper-like plant, which the tree peony is not.

The phrase 'lingdong budiao' 凌冬不调 appears in Tao's commentaries on rendong 忍冬 (also known as jinyinhua 金銀花), nüzhen 女貞, and in the Xinxiu bencao's description of shinan 石南. Nowadays, those drug ingredients are considered to be evergreen plants, Lonicera japonica Thunb.(semi-evergreen), Ligustrum lucidum Ait., Piper wallichii (Miq.) Hand.-Mazz. It can, therefore, be inferred that 'lingdong budiao' translates as 'leaves remain during winter'.

In the second section, two aliases of the môgtan, bailiangjin and wu-môgtan, are introduced:

The indigenous people of Jiannan 劒南 call [it] 'mudan' and [it is] also named 'bailiangjin 百兩金.' The people in Chang'an call [the] genuine [môgtan] ' $\underline{w u-}$ mogtan 吳牡丹.' The [counterfeit] mudan used in folk remedies nowadays is different; it has bad smell.

The Chinese character ' $w u$ 吳' is associated with the Jiangnan 江南 region. At that time, ordinary physicians, incorrectly, used another plant in medications, and noted that it had a particular smell. In fact, the roots of the tree peony have a peculiar smell, which is mainly due to the chemical component paeonol $\left(\mathrm{C}_{9} \mathrm{H}_{10} \mathrm{O}_{3}\right) .{ }^{40}$ In this sense, the incorrectly used herbs are actually more like tree peonies than genuine môgtan are.

I have shown that all references to the mogtan before the eighth century suggest that its identification as the tree peony is disputable: Xie Lingyun wrote that mogtan grew in Wenzhou, whereas wild tree peonies grow badly there; Tao wrote that the bajitian looks very much like môgtan, which is very different in form from the tree peony; and the features of môgtan described in Xinxiu bencao are quite different from those of the tree peony. When then, did 'môgtan (mudan)' begin to refer to the tree peony?

\section{Cultivation of mudan as ornamental plants}

During the rule of Xuanzong 玄宗, mudan (môgtan) suddenly became ubiquitous in Chinese literature, and was cultivated for ornamental purposes. Did this mudan refer to the same plant as in the earlier literature, or to the tree peony?

${ }^{40}$ Arichi et al. 1979 , pp. 178-184. Paeonol has anti-inflammatory and analgesic action. The roots also contain another chemical component, paeoniflorin $\left(\mathrm{C}_{23} \mathrm{H}_{28} \mathrm{O}_{11}\right)$. This has muscle relaxant action. 


\section{The Shengtang 盛唐 era (713-765 CE): the beginning of cultivation}

During Shengtang era, the famous poet, Wang Wei 王維 (701-761 CE) composed a poem about the tree peony: Hong mudan 紅牡丹 (red mudan). ${ }^{41}$ This poem is one of the earliest poems in existence that contains the word 'mudan'. In the last phrase of the poem, he uses the word 'chunse 春色' (spring scenery), implying that the plant bloomed in spring, whereas it was said in Xinxiu bencao that môgtan bloomed in summer.

A Chinese intellectual, Li Jun 李濬, left in Songchuang zalu 松牕雜錄 a significant account of the beginning of the cultivation of the plant, in which he confirms that the plant that came to be known as 'mudan' later, was called 'mu-shaoyao' when it was first cultivated as an ornamental plant.

In the Kaiyuan 開元 period, the mu-shaoyao 木苟藥 was first respected in the inner court. [The mushaoyao is] namely the present-day mudan. Four mudan, red, violet, light-red and translucent white were delivered. The emperor [Xuanzong] instructed these to be planted in front of Chenxiang Ting 沈香亭, which was located to the east of Xingqing Chi 興慶池. ${ }^{42}$

'Mu 木' refers to wood or trees and 'shaoyao 芶藥' refers to herbaceous peonies, so there is no doubt that 'mu-shaoyao' is the early Chinese term for the tree peony and that it was only later that people began to call it 'mudan'. In the above story, Li Jun goes on to write about Li Bai 李白 (701-762 CE) at court. One day, when Xuanzong saw the flowers of mudan in the court garden he requested that $\mathrm{Li}$ Bai compose a lyric poem, $c i$ 詞, in the rhythm qingping diao 清平調. ${ }^{43}$ However, Li Bai did not use the word 'mudan', but depicted it with the character 'bua 花' (a flower) and a phrase 'yizhi hongyan 一枝紅灔' (a branch with a flush [blossom]).

At this time, Li Bai worked in the inner court. Wang Wei, who has also written poems mentioning mudan, was often invited to visit the imperial family and nobles during the Kaiyuan and Tianbao 天寶 (742-756 CE) eras because his poems were highly praised among them. ${ }^{44} \mathrm{On}$ the other hand, $\mathrm{Du}$

${ }^{41}$ Chen Tiemin 1997, p. 640. “紅牡丹, 綠艶閒且靜, 紅衣淺復深. 花心愁欲斷, 春色豈知心.

${ }^{42}$ Li Jun 1991 [c. 800], p. 2. ‘開元中禁中初重木苟藥, 即今牡丹也. 得四本紅紫淺紅通白 者. 上因移植興慶池東沉香亭前’ Translation by T. Kubo. The author Li Jun is probably the son of Li Shen 李紳. Though he wrote in the Wantang era, his accounts are relatively reliable. “書中 記唐明皇事, 頗詳整可觀. 通鑑所載[李]泌事, 多採取李㢣鄴侯家傳. 㵶悉必錄, 而獨不及此 語。是亦足以補史䦕. (Yong Rong et al. 1986, p. 946.)'

43 Ibid. “沈香亭前會花方繁開. 上乘月夜召太真妃... 上曰賞名花對妃子焉用舊樂詞為, “想衣裳花想容... 一枝紅艶露凝... 可憐飛燕倚新粧, 名花傾國兩相歡”.

44 Liu Xu et al. 1975 [945],pp. 5052-53. “維以詩名盛於開元, 天寶間. 昆仲宦遊兩都, 凡諸 王駙馬豪右貴勢之門, 無不拂席迎之. 寧王, 薛王待之如師友. Ouyang Xiu et al. 1995 [1060], p. 5779. ‘[王]維私邀入內署, 俄而玄宗至, [孟]浩然匿禱下, 維以實對...’ 
Fu 杜甫 (712-770 CE), who was praised as a poet sage (Shi Sheng 詩聖), but could not work in the court during the Xuanzong's reign, does not mention the mudan in his poetry. This implies that in the Shengtang era the tree peony was only cultivated in a few gardens of the inner court and its executives, and had not yet been popularised among the majority of people. ${ }^{45}$

At the end of the Shengtang era, the An Lushan 安祿山 rebellion (755-763 $\mathrm{CE}$ ) occurred. In the summer of $756 \mathrm{CE}$, the emperor Xuanzong had to withdraw to Shu 蜀 (present-day Sichuan province) with his family and entourage, and the palace in Chang'an fell empty. The following spring, capital citizens were, for the first time, able to see the flowers in the gardens of the inner court and executives. They probably referred to the tree peony by its vernacular name 'mudan'.

During the Shengtang era, the tree peony gradually assumed the name: 'mudan'. The following evidence shows that mudan only came to refer to the tree peony in this era, but since then the word has never referred to any other type of plant, including that described in Xinxiu bencao.

\section{The Zhongtang 中唐 era (766-835 CE): cultivation popularised}

In the Zhongtang era, it was not only in the inner court that the mudan was eulogized: even common people in the capital Chang'an went out each spring to appreciate its flowers. ${ }^{46}$ Bai Juyi 白居易 (772-846 CE) wrote: 'In the twenty days from blooming to the flower's withering, people in the city become near crazy. ${ }^{\text {'77 }}$ It was a remarkable social phenomenon: no other flower in Chinese history has matched the popularity of the tree peony. In another poem, Bai tells us:

An old man from the countryside happens along where they're buying flowers, head bent, heaves a long, lonely sigh, a sigh whose meaning no one understands. One cluster of these deep-hued blossoms would pay the taxes for ten ordinary families! ${ }^{48}$

\footnotetext{
${ }^{45}$ For example, a high-level official, Pei Shiyan 裴士淹 brought mudan (the tree peony) to the temple of Fenzhou 汾州 (see figure 1) and planted it in his residence. (Duan Chengshi 1981 [c. 860], p. 185. “開元末, 裴士淹為郎官奉使幽冀. 迴至汾州衆香寺, 得白牡丹一巢, 植於長安 私第. 天寶中為都下奇賞.'

${ }^{46}$ For details, see Ishida 1967 [1941]; Li Shutong 1972.

${ }^{47}$ Zhu Jincheng 1988, pp. 218-221. ‘牡丹芳... 花開花落二十日, 一成之人皆若狂.' Translation by T. Kubo.

${ }^{48}$ Watson 2000, p. 19. ‘買花... 有一田舍翁, 偶來買花處. 低頭獨長嘆, 此嘆無人喻. 一叢 深色花, 十戶中人賦.'
} 
Also, a poet in the Wantang era, Xu Yin 徐夤 wrote:

A hundred thousand families in Chang'an were bankrupted. The instinct for beauty took away their thrifty minds. Spring brought glamour and millionaires were poisoned. ${ }^{49}$

Since the Zhongtang era, people in Chang'an had been trading tree peonies for high prices as commercial products and some people were cultivating tree peonies for the purposes of speculation. ${ }^{50} \mathrm{~J}$. Needham remarked that a social situation arose comparable only with the 'tulipomania' of 17 th century Holland. ${ }^{51}$ With increasing commerce, the appearance of feiqian 飛錢 (flying cash) facilitated 'big-ticket' deals and some people attempted to make their fortunes in the tree peony trade. Therefore, the tree peony became well-known among ordinary citizens under the erroneous name 'mudan'.

\section{The Wantang 晚唐 era (836-907 CE): cultivation spreads into the southeast}

Today, tree peonies are cultivated in several gardens in Jiangnan 江南, which raises the question of when the Chinese began to grow tree peonies there. In the Wantang era, there was a rumour that a Buddhist monk of the preceding era first cultivated tree peonies successfully at the temple of Kaiyuan Si 開元寺 in Hangzhou 杭州 (a city in the Jiangnan region), and that Bai Juyi saw this peony when he went there. ${ }^{52}$ In the story, the monk covered the tree peony with an oiled curtain. The sunshine in the southeast is stronger than in the northwest, so the use of the curtain seems quite practical. Bai had been to Hangzhou 杭州 and Suzhou 蘇州 in the years 822 to 826 CE (during the Shengtang era), as a Cishi 刺史 (Regional Inspector). If Bai saw tree peonies in Jiangnan, it must have been cultivated there before the Wantang era.

Yet Bai himself never wrote of these peonies, and, in $833 \mathrm{CE}$, when he met his colleague Li Shen 李紳 in Luoyang 洛陽, Bai told him: '... You had better see well the last [mudan, i.e. tree peonies] after the people leave. Back in Jiangnan,

\footnotetext{
49 Peng Dingqiu et al. 1960 [1706], p. 8150. '牡丹花, 看徧花無勝此花... 破却長安千萬

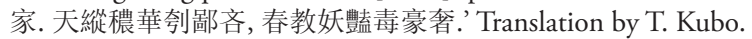

${ }^{50} \mathrm{Li}$ Zhao 1957, p. 45. “京城貴遊尚牡丹三十餘年矣, 每春莫車馬若狂. 以不䠶玩為恥. 執 金吾鋪官圍外寺觀種, 以求利一本有直數萬者.

51 Needham 1986, p. 398.

52 Fan Shu 1957, p. 31. The story is recorded in Yunxi youyi 雲溪友議 by Fan Shu, in the Wantang era. In the Sikuquanshu tiyao 四庫全書提要, it was established that the contents of that book were founded on rumour and are not reliable (“皆委巷流傳, 失於考證, Yu Jiaxi 1958, pp. 1023-31).
} 
there is no flower like this yet'. ${ }^{53}$ Li's home city was Wuxi 無錫, Jiangnan; he therefore would have known whether tree peonies were cultivated in Jiangnan, and he retuned there as Zhedong guancha shi 浙東觀察使 (the governor of Zhedong) in the leap month (Run Qiyue 潤七月) of that year. Thus, in the year $833 \mathrm{CE}$ when they met each other, they would not have been able to see tree peonies in Jiangnan.

At least two poems written in the Wantang era do mention mudan: Hangzhou Kaiyuan Si Mudan 杭州開元寺牡丹 (Tree Peonies at the Temple Kaiyuansi in Hangzhou) by Zhang $\mathrm{Hu}$ 張祜 (792-852 CE) ${ }^{54}$ and Guan Jiangnan mudan 觀江南牡丹 (Viewing Tree Peonies in Jiangnan) by Zhang Bin 張蝜 (c. the Wantang era). Hence, it can be assumed that tree peonies had been grown successfully by the Wantang era.

\section{From the Five Dynasties onward}

In $907 \mathrm{CE}$, the last emperor of Tang, Aidi 哀帝 was forced to abdicate the throne by Zhu Quanzhong 朱全忠, and China plunged into the turbulent period of the Five Dynasties (Wudai shiguo 五代十國). Though northern China was deeply drawn into the vortex of war, the southern parts of China remained relatively peaceful. As a result, mudan were mainly cultivated and appreciated by people in the Shu 蜀 and Jiangnan regions. ${ }^{55}$

In the following dynasty, mudan was again highly praised, particularly in the Jiangnan region and the capital Luoyang. In $1062 \mathrm{CE}$, the emperor ordered Su Song 蘇頌 et al. to edit another illustrated bencao book, i.e. Tujing bencao 圖經本草. As shown below, the features of mudan described in Tujing bencao are almost completely consistent with those of the tree peony, and its illustration of mudan closely resenbles the tree peony (figure 3).

53 Zhu Jincheng 1988, pp. 737-38. ‘看渾家牡丹花戲贈贈李二十...人人散後君須看, 歸到 江南無此花.' Translation by T. Kubo. Li Shen is an uncle or father of Li Jun 李㴭, who wrote Songchuang zalu 松牕雜錄.

${ }^{54}$ According to Yunxi youyi, when Zhang Hu met Bai Juyi in Hangzhou, he composed this poem. However, Zhang Anzu concluded it is a fictional narrative after his investigation (Zhang Anzu 1995, pp. 77-81).

55 Huang Xiufu 2006 [c. 1018], pp. 58-9. ‘西蜀自李唐之後未有此花, 凡圖畫者唯名洛州 花 ... 徐延瓊新創一宅 ... 唯無牡丹 ... 或聞秦州董城村僧院有紅牡丹一樹.... 歷三千里至 蜀植于新宅.' 


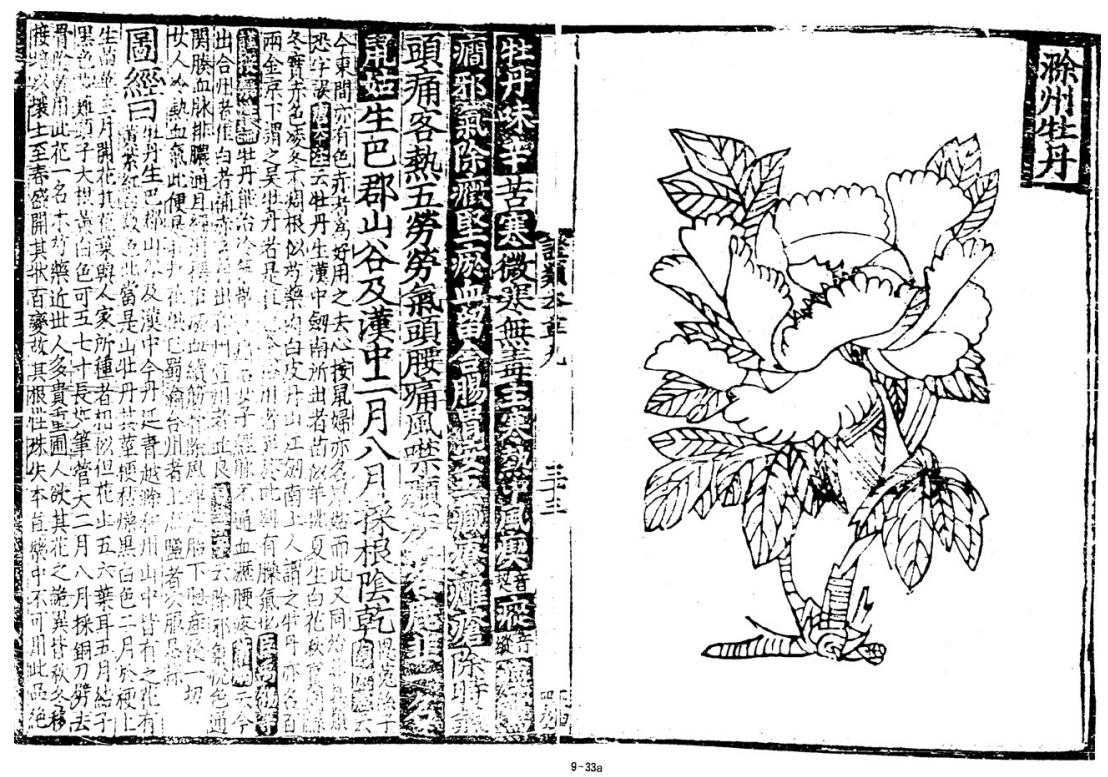

Fig. 3. Chuzhou Mudan 涂州牡丹 56 (the Illustration originated in Tujing bencao 圖經本草 (1061 CE), printed in $1211 \mathrm{CE})$.

In Tujing bencao, bailiangjin 百兩金 first entered bencao books (figure 4). ${ }^{57}$ This is a remarkable entry because bailiangjin was originally an alias of môgtan in Xinxiu bencao, but the editors of Tujing bencao separated it from mudan. In this bencao text, bailiangjin is described as follows:

Bailiangjin ... the leaf looks like one of litchi; both sides of the leaf at a seedling are green. After flowering and producing fruits, the abaxial side turns violet but the adaxial side remains green; the height of miao is approx. 2-3 chi 尺 (0.6 to $1.0 \mathrm{~m})$; it has a stalk like a tree; enduring winter without withering (凌冬不调); blossoming blue-green flowers in early autumn; the seeds are as large as beans; young

56 Tang Shenwei 1992 [1108] vol. 3: 186-187.

57 In the Shengtang era, Chen Cangqi 陳藏器 collected drugs neglected previously and published Bencao shiyi 本草拾遺 (Additions to the materia medica) in 739. The ten chapters of his work included one chapter with preface and introduction, six chapters on 'matters that have been neglected,' and three chapters on 'explanations of obscure points.' The original as an independent work has been lost, but its important commentaries were quoted in the subsequent Bencao work. (Unschuld 1985, pp. 50-1.) Recently, Shang Zhijun 尚志鈞 collected the fragments and published Bencao shiyi jishi 本草拾遺輯釋 in 2002, but in his collected work neither mudan nor bailiangjin has ever been included. (Shang Zhijun 2002.) 


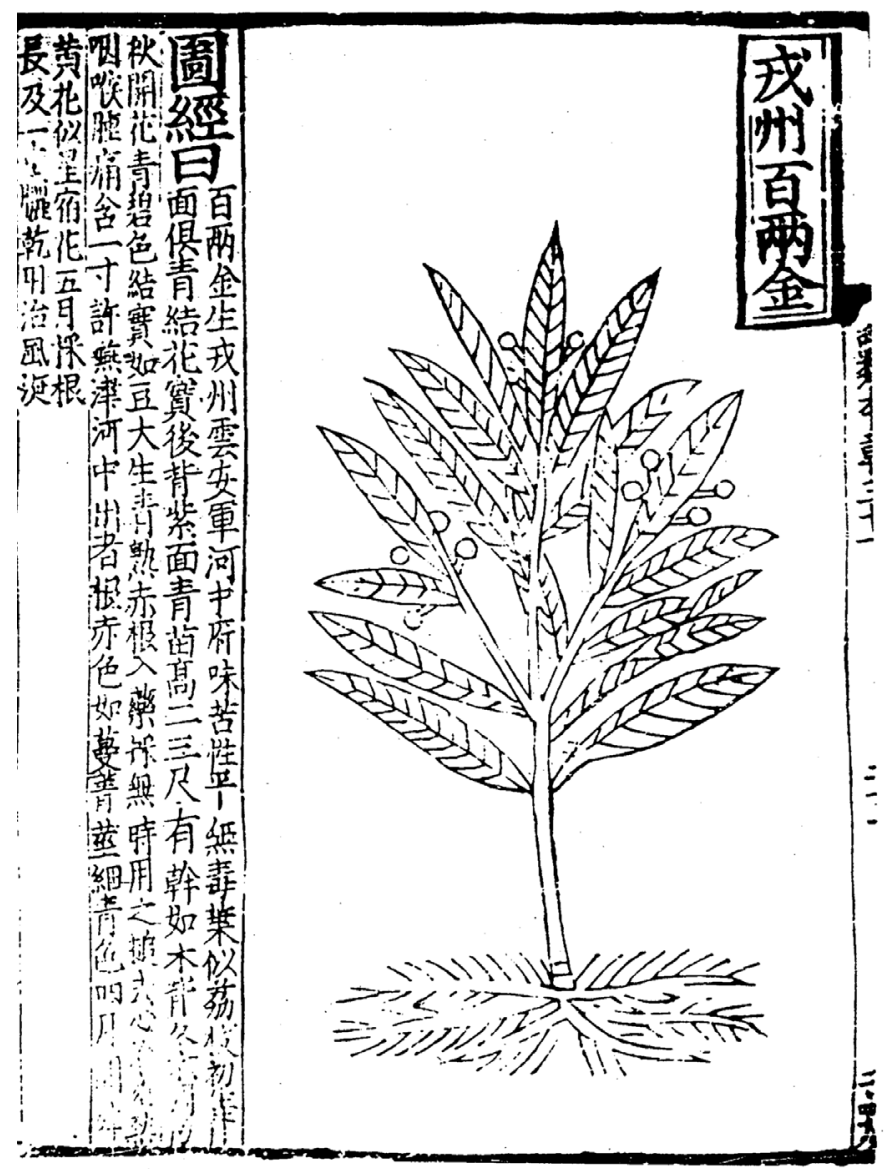

Fig. 4. Rongzhou bailiangjin 戊州百兩金 ${ }^{58}$ (the Illustration originated in Tujing bencao 圖經本草 $(1061 \mathrm{CE})$, printed in $1211 \mathrm{CE}$. It seems to be a pressed specimen) Rongzhou is now called Yibin 宜賓, located in the Sichuan.

fruits are green and ripe fruits are red; their roots can be used for drugs. They can be gathered in any season; before using, the roots should be pounded to remove the cores and then swallow it with saliva. The ones in Hezhong 河中 have red roots like creepers. The stalk is thin and green. In the forth lunar month they blossom small yellow flowers like xingsu hua 星宿花. ${ }^{59}$

58 Tang Shenwei 1992 [1108] vol. 5: 390.

59 Tang Shenwei 1992 [1108] vol. 5: p. 390; Tang Shenwei 1970 [1108], p. 592; Tang Shenwei 1957 [1108], p. 527. “百兩金...葉似荔枝, 初生背面俱青. 結花實後, 背紫面青. 苗高二三尺. 
This plant hardly has any similarities to the mudan described in Tujing bencao, but there are a few common features with mogtan in Xinxiu bencao, such as the fruit and its endurance of winter without withering.

\section{Introduction of the tree peony in western countries}

During the Ming dynasty in China, a western mission was sent by the Dutch East India Company, who saw mudan. They introduced it to the West in 1656 $\mathrm{CE}$ along with the report below:

In Sichuan Province, near Chung-King, grows a special plant named meutang. This one is unusually protected and is named the king of flowers. It is similar to a European rose, but is much bigger, with prostrate leaves. Its beauty too is much greater than that of rose, but it cannot compare in fragrance; it does not have spines and is mostly white or purple, but some are yellow or pink. This plant grows as shrub and is carefully protected and planted in all gardens, cherished by aristocrats as their favourite plant. ${ }^{60}$

The sound of 'meutang' is close to 'moutan', the middle Chinese pronunciation of 'mudan'. The descriptions of 'meutang' also matches features of the tree peony. Joseph Banks (1743-1820), president of the Royal Society of London (1778-1820), procured plants for the Royal Gardens at Kew. He engaged the botanist Alexander Duncan to collect seeds and specimens, and Duncan then sent tree peonies to Kew in $1789 .{ }^{61}$ The plant was named Paeonia suffruticosa (Syn.: P. moutan) by a British botanist, Henry Andrews in $1804 .{ }^{62}$ Today, most cultivated varieties of the tree peonies are considered to be Paeonia suffruticosa. However, the origin of the wild variety is still obscure.

\section{The Tree Peony in Early Chinese Art}

When describing the history of the tree peony in China, we must not forget its role in the history of Chinese art. One theory has it that the tree peony may have captured the imagination of early Chinese artists before the Shengtang era. If so, some early Chinese may have already praised the beauty of the tree peony, regardless of which nomenclature they used, mudan, shaoyao or another.

\footnotetext{
有幹如木. 凌冬不调. 初秋開花青碧色, 結實如豆大. 生青熟赤. 根入藥, 采無時. 用之搗去心. 河中出者, 根赤色, 如蔓菁, 婳細, 青色. 四月開黃花, 似星宿花.' Translation by T. Kubo.

${ }^{60}$ Smrž 1925, pp. 47-48. Translation by Halda and Waddick 2004, p. 151.

${ }^{61}$ Stern 1946, p. 15.

${ }^{62}$ Andrews 1804, p. 373.
} 
This section explores two early paintings and an engraved figure, where it has been asserted that tree peonies were drawn before the Shengtang era.

\section{Luoshen Fu Tu 洛神賦圖 (the Goddess of the Luo River)}

A group of Chinese scholars recently asserted the tree peony appears in Luoshen Fu Tu 洛神賦圖 (figure 5) by Gu Kaizhi 顧愷之 (c. 344-406 CE). ${ }^{63}$ However, the original painting of Gu Kaizhi is already lost, and moreover, the three copies attributed to the Song dynasty survive. Thus, strictly speaking, the painting may not have been faithfully copied from the original work by $\mathrm{Gu}$ Kaizhi. Certainly several plants, such as lotuses, appear in the copies, but most of them are hard to identify. Luoshen 洛神 is an goddess believed to reside in the Luo 洛 river, and the Luo river takes its major water from among the Qinling 秦嶺 mountains in the southern part of Shaanxi province. It runs through the south of Luoyang 洛陽 and connects with the Yellow river. The background of Luoshen $F u T u$ was, therefore, supposed to be drawn from the headwaters, which is close to the home place of wide tree peonies. That may be the foundation of this argument.

Secondly, in Shangshu gushi 尚書故實, Li Chuo 李綽 of the Wantang era stated that he had heard of a tree peony painting by a famous painter of the Beiqi 北齊 dynasty (550-577 CE). He wrote:

People have said that mudan (the tree peony) appeared recently. That is because neither a song nor a poem about tree peonies survives in the works of intellectuals of this [early] present empire. [Yet] Mr Zhang 張 said Yang Zihua 楊子華 has already captured a tree peony in his painting. [The existence of such painting] is clear proof. [Yang] Zihua was living in the Beiqi 北齊 dynasty. That is to say actually the flowers of the tree peony have already been appreciated for a long time. ${ }^{64}$

However, this tree peony painting was not recorded in of Zhang Yanyuan's 張彥遠 early book about history of Chinese art, Lidai minghua ji 歷代名畫 記 (the Famous Painters of all Dynasties, $854 \mathrm{CE}$ ), ${ }^{65}$ although he did introduce various paintings and artists including Luoshen fu tu by Gu Kaizhi, as well as Mudan hua 牡丹畫 (Painting of Tree Peonies) by Bian Luan 邊鸞, an artist during the Zhongtang era. He also wrote about Yang Zihua, but did not mention his tree peony painting. If Yang truly drew tree peonies, that should

${ }^{63}$ Dai Songcheng et al. (eds) 2008, pp. 4-6. ‘牡丹用作觀賞栽培約始于東晉. 東晉大畫家顧 愷之在他的傳世之作《洛神賦圖》中描繪了牡丹花, 他的其他畫作中還出現了庭院牡丹.'

${ }^{64}$ Li Chao 1936, p. 7. '世言牡丹花近有, 蓋以國朝文士集中無牡丹謌. 張公嘗言楊子華有 画牡丹處極分明. 子華北齊人, 則知牡丹花亦已久矣.'

${ }^{65}$ Zhang Yanyuan 1963, p. 57. ‘北齊) 楊子華(中品上)... 世祖重之, 使居禁中. 天下號為 畫聖...斛律金像, 北齊貴戚遊苑圖, 官苑人物屏風, 鄴中百戲, 獅猛圖, 並傳於代.' 
be a remarkable work because the tree peony was highly praised in the Wantang era when Zhang Yuanzhi [yuan?] lived. Thus, Yûjiro Tanaka, a Japanese scholar, threw doubt on the existence of that painting, and has already concluded that the comment by Mr. Zhang is insufficient to prove that the tree peony was praised by Chinese people in the Southern dynasties. ${ }^{66}$

Yongtai Gongzhu Mu 永泰公主墓 (Tomb of Princess Yongtai)

Thirdly, Meng Qingyuan 孟慶元 suggests that images of the tree peony were engraved in Yongtai gongzhu mu 永泰公主墓 (figure 6). ${ }^{67}$ Although he did not specify which figure, he was probably suggesting that engraved figures like those shown in figure 6 were drawn from the tree peony. Yongtai 永泰 (685$701 \mathrm{CE}$ ), who was a granddaughter of the empress Wu Zetian 武則天, was buried in Qianxian 乾縣 after her death at sixteen. Qianxian is located near Chang'an where tree peonies were possibly used instead of the genuine mudan which came from the Chutang era as discussed above. However, many other plant forms are actually too fictitious to recognise. Such figures were probably influenced by a particular style of pattern, so-called Baoxiang hua (wen) 寶相花 (紋). These engraved figures can not sufficient proof that tree peonies were already appreciated by Chinese in the Chutang era after all.

As with the textual descriptions, there are some conjectures but no absolute proof of the existence of the tree peony in Chinese art before the Chutang era. It is such a mystery that the beauty of the tree peony was ignored by the ancestors that many intellectuals must have been stirred to search for early descriptions and paintings of tree peonies, in order to find historical evidence for their existence.

\section{The Tree peony In Chinese art from Shengtang to the Five Dynasties}

During Shengtang it became fashionable among Chinese painters to capture tree peonies in their art. Ji hua 雞畫 (Chicken Painting) by Feng Shaozheng 馮紹正 of the Shengtang era, and the Mudan hua 牡丹畫 (Tree Peony Painting) by Bian Luan 邊鸞 of the Zhongtang era, both contained tree peonies but are no longer extant. Extant depictions include Mudan luyan tu 牡丹蘆雁圖 (Painting of Tree Peonies, Reeds and Wild Geese) in the tomb of Wang Gongshu

\footnotetext{
66 Tanaka 1962 , p. 39.

${ }^{67}$ Meng Qingyuan 1980, p. 385.
} 


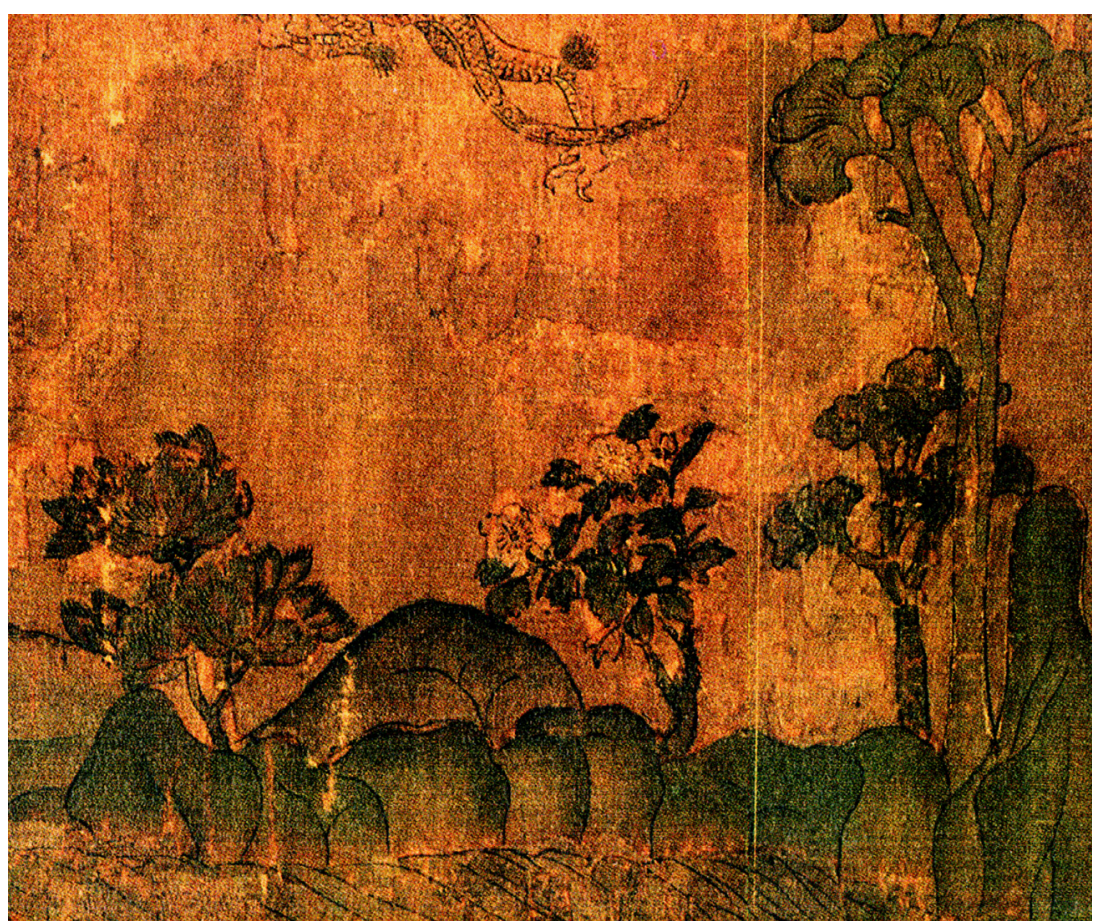

Fig. 5. Luoshen Fu Tu (part, in the possession of Liaoning bowuguan 遼寧博物館). ${ }^{68}$ Perhaps, the middle figure is interpreted as a tree peony.

王公叔 and his wife (the Wantang era); Mudan 牡丹 by Teng Changyou 滕 昌佑 dating to the end of the Tang dynasty; and Yutang Fugui Tu 玉堂富貴 圖 by Xu Xi 徐熙 of the Five dynasties.

Zanhua Shinü Tu 䙃花仕女圖 (Court Ladies Adorning Their Hair with Flowers, figure 7) was previously attributed to Zhou Fang 周昉 (c. the Shengtang era). However, not a few scholars such as Shen Congwen 沈從文 insisted that it is doubtful that the painting was drawn by Zhou Fang because adorning heads with a big fresh flower is not the fashion of the Tang, but of the Song dynasty. ${ }^{69}$

${ }^{68}$ Jiangsu Meishu Chubanshe (ed) 2000a, p. 7.

${ }_{69}$ Shen Congwen 1981, p. 70; Furuta 2003, pp. 13-39. 

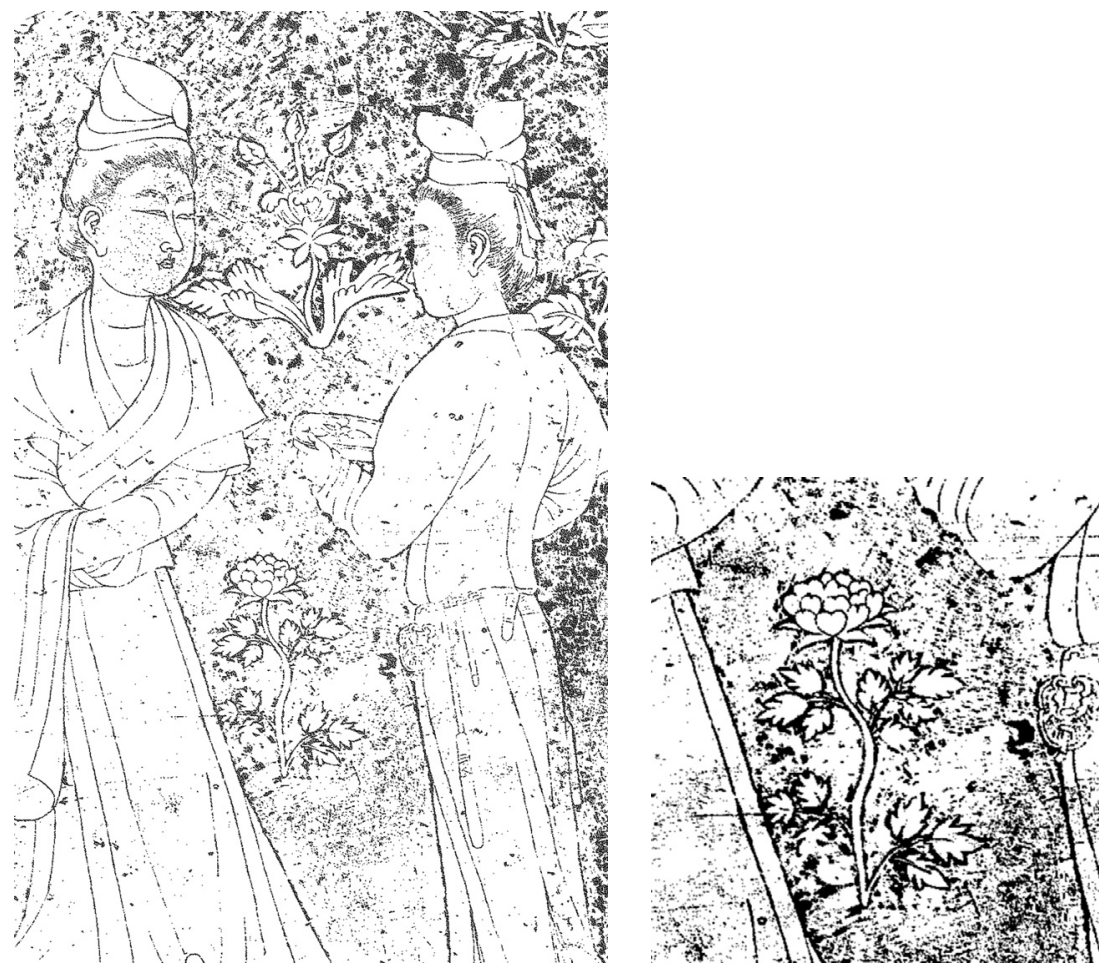

Fig. 6. Graved figures in Yongtai gongzhu mu (part). ${ }^{70}$ The original photograph is black on white, so the above two pictures are inverted. Observing the picture collection Yongtai Gongzhu Mu Shiguoxianhua, 永泰公主石楟線畫, the figure shown in the right picture should be the most likely candidate of the tree peony by referred by Meng Qingyuan. The shape of its indented leaves looks similar to the leave of the tree peony rather than herbaceous peonies (Photograph by Luo Zhongmin 羅忠民).

In summary, thus far I have demonstrated that Chinese people have appreciated the tree peony since the Xuanzong's reign, while cultivating it as an ornamental plant in their gardens, but in the Chutang era and pre-Tang dynasty, mudan had referred to a different plant. In fact, a similar situation occurred in early Japan. In the following chapter I will consider the appearances of the word 'mudan' in early Japanese texts.

${ }^{70}$ Shanxisheng bowuguan (eds) 1981, p. 2. 

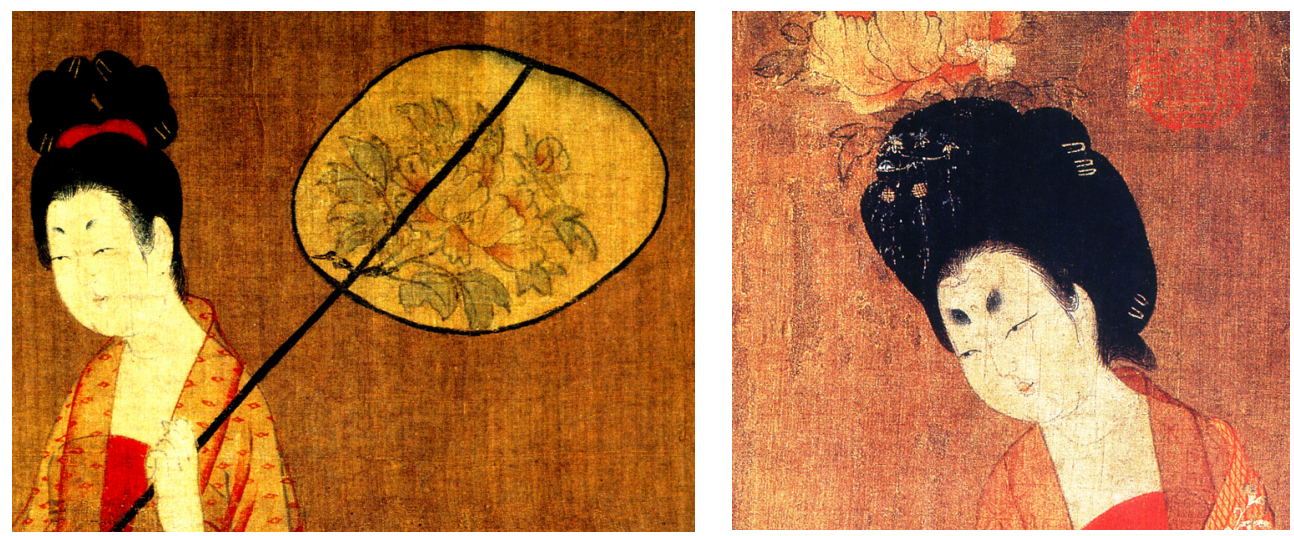

Fig. 7. Zanhua Shinü Tu 穊花仕女圖 ${ }^{71}$

\section{Botan (môgtan) 牡丹 in Japan}

In Japan, there is another dubious description of môgtan, which is pronounced 'botan' in contemporary Japanese. No wild variety of tree peony has been discovered in Japan. However, the word botan (môgtan) first makes an appearance in a Japanese book written in $733 \mathrm{CE}$, at precisely the same time that the tree peony was first cultivated as an ornamental plant in China. Does 'botan' in this book refer to the tree peony, or another plant?

\section{Botan in early Japanese texts}

Izumonokuni fudoki 出雲國風土記 (Gazetteer of the Province of Izumo) is one of the early Japanese gazetteers, and was compiled in $733 \mathrm{CE}$. In this book, botan was recorded as a plant native of the province of Izumo (the eastern part of Shimane 島根 Prefecture)..$^{72}$ However, wild tree peonies do not grow there. Again, the year $733 \mathrm{CE}$ is the time when the tree peony was praised by the Chinese emperor. Thus, Japanese historians, K. Gôto, Y. Katô and R. Hashimoto, thought that the text was referring to a different plant, but were unable to identify the most likely candidate. ${ }^{73}$

${ }^{71}$ Left: Chen Xueliang (ed) 2006, p. 20, Right: Jiangsu meishu chubanshe 2000b, p. 20.

72 Gotô 1926, pp. 73, 169.

73 Ibid. p.73; Katô 1962, pp. 161-65; Hashimoto 1986, pp. 62-66. 
In 918 CE, a Japanese court physician, Sukehito Fukane 深根輔仁 (or S. Fukae 深江), remarked in his book, Honzô Wamyô 本草和名, that the botan had two aliases: 'fukami-kusa 布加美久佐' and 'yama-tachibana 也末多知波奈”. ${ }^{74}$ Though the etymology of fukami-kusa remains unknown, yamatachibana can be interpreted as follows: 'Yama 山' refers to mountain(s) and 'tachibana 橘' is used in Japanese as a generic term for citrus trees. The alias therefore implies that the plant described in the text is associated with citrus plants.

According to another historical record, Engi shiki 延喜式 (Regulations and Laws of the Engi Era, $927 \mathrm{CE}$ ), the Bizen 備前 province was obligated to bring thirty kinds of drug ingredients as annual tributes to the Japanese court, including ten kin 斤 of botan. Around that time botan ${ }^{75}$ could be supplied internally in Japan.

In early Japanese literature, Japanese poets use yama-tachibana as a metaphor for love. The first major anthology of early Japanese poetry, Manjyôsh $\hat{u}$ 萬葉集 (c. $759 \mathrm{CE}$ ), contains five poems including yamatachibana. ${ }^{76} \mathrm{Also}$, Kokin wakash $\hat{u}$ 古今和歌集 (905 or $914 \mathrm{CE}$ ), contains the following poem:

No longer able to hide/ to hide this tender passion. I must let it show/

As show the scarlet berries of yamatachibana in the hills. ${ }^{77}$

From these poems, it can be presumed that the yamatachibana was a common plant in the gardens of Japanese nobles. In contrast, the word 'botan' never appeared in early Chinese poetry composed by Japanese, such as Kaifûsô 懷風藻 $(751 \mathrm{CE})$, Ryôun Shî 凌雲集 $(814 \mathrm{CE})$ and the Bunka shûrei shî 文華秀麗集 $(818 \mathrm{CE})$, though the tree peony is an exotic flower from China and was highly priased in this period of China. ${ }^{78}$ If tree peonies had been cultivated successfully in Japan, there is no reason for them to be ignored in

${ }^{74}$ Fukane 1928 [918], 32b-33a. Incidentally, In 754, A famous monk Jianzhen 鑒真 (668763), who had once studied medicine in Chang'an, arrived at the capital in Japan, Nara 奈良. He also brought drugs from China, and introduced the latest Chinese medicine into Japan.

75 Fujiwara et al. 1985 [927], p. 840. Shokoku shinnenryô zatsuyaku 諸國進年料雜藥. Bizen 備前 is the former province, which consisted of the southeastern parts of Okayama 崗山 prefecture.

76 Satake et al. 1999, p. 394. (Poem 0669; 1340; 2767; 4226; 4471).

77 McCullough 1985, Poem 668. 我が戀は/忍びかねては/あしひきの/山橘の/色にいでぬべし.’ Yamatachibana is translated as 'ardisia' by McCullough. For convenience, in this paper it has been replaced with the original Japanese word, yamatachibana.

${ }^{78}$ The oldest Chinese poem that mentions botan was Hokkeji haku-botan 法花寺白牡丹 (The white mudan in the Hokkeji temple) by Sugawara-no Michizane 菅原道眞 (Kawaguchi (ed.) 1966, p. 306; 422-23). In 895, he wrote another poem, entitled Botan 告丹. Early Japanese poets sometimes imitated famous Chinese poems, despite having never seen the inspiration for the originals. Therefore, it cannot be presumed that the Japanese cultivated tree peonies in the late ninth century. 
those poems. While yamatachibana was a common plant well known among the Japanese intellects, they had probably not yet seen tree peonies.

In addition, southeast China and central Japan belong to the Humid Subtropical Climate (Cfa) category in the Köppen Climate Classification, and cultivation of the tree peony would have been as difficult in Japan as in the south-eastern parts of China. As shown in above, its cultivation in the Jiangnan region began around the Wantang era (836-907 CE). Thus, 'botan' in Izumonokuni fudoki and other early Japanese texts is unlikely to refer to the tree peony, however, the exact nature of the plant to which they refer remains unknown.

\section{Cultivation of the tree peony in Japan}

When then, was the tree peony introduced into Japan? The mother of Fujiwara—no Michitsuna 藤原道綱 mentioned tree peonies in her diary, Kagerô $n i k k i$ 蜻蛉日記 (Kagero Diary). She wrote that she saw flagging 'boutan sou ぼうたん草’ in the sixth lunar month of 984 CE. ${ }^{79}$ Although she used Japanese phonogram 'Kana character', the word 'boutan' corresponds to 'montan', the middle Chinese pronunciation of 'mudan'. As the sixth month is close to the end of the peony's flowering season, it is possible that she saw tree peonies. About ten years later, botan again appeared in Makurano $s o \hat{s} h i$ 枕草子 (Pillow book, c. 1000 CE) by Sei Shônagon 清少納言. According to an account from the book, her colleague told her, 'botan in front of the terrace have a delightful Chinese art' ${ }^{80}$ Here, botan was described as a Chinese flower and thus clearly refers to the tree peony. It can, therefore, be ascertained that the Japanese had successfully cultivated tree peonies by the late tenth century.

\section{Separation of yamatachibana from mudan}

As shown above, early Japanese poets before the Kagerô nikki often mentioned yamatachibana in Japanese literature, but did not use the Chinese word 'botan'. In the tenth century, the mother of Fujiwara-no Michitsuna and Sei Shônagon mentioned botan, which can be considered to refer to the tree peony in this instance.

79 Kakimoto 1966, p. 420.

${ }^{80}$ Ikeda 1962, p. 198. “露台の前に植えられたりける牡丹の, 唐めきをかしきこと.’ Translation by McKinney 2006, p. 163. Botan is translated as 'the peonies' by McKinney. As a matter of convenience, here it has been replaced with 'botan'. 
Remarkably, Sei Shônagon also mentioned yamatachibana elsewhere in the same book.

(Sei Shônagon said to Empress Sadako 定子) 'I have a letter from the High Priestess,' I relied, 'which I had to deliver to Your Majesty as quickly as possible.' 'Well,' she said, getting up, 'it certainly is early for a letter.' Looking inside, she discovered a pair of hare-sticks (Uzue 卯杖), each about five inches (sun 寸) long. They had been placed end to end so that wrapped round the head of the sticks, which were prettily decorated with sprigs of yamatachibana, club moss, and mountain sedge. But there seemed to be no written message. ${ }^{81}$

This to us implies that she considered the mudan, or the tree peony, to be a different plant from the yamatachibana, which indicates that since the eleventh century, yamatachibana has been considered to be a different plant from the tree peony, and the word was never used as the synonym of botan, except by modern scholars talking about classical literature.

In the Edo period, Ekken Kaibara 貝原益軒 wrote in Yamato honzô 大和本草 (1709) that the yamatachibana was commonly called 'yabukauji ブカウジ'.82 Yabukauji ( yabukôji) now generally refers to the Ardisia species, specifically the A. japonica Thunb. (figure 8). Uzue 卯杖, as it appears in Makurano Soshi, remains a traditional Japanese decoration for the New Year and sprigs of A. japonica are commonly combined with it.

Today, A. japonica is known as 'zijinniu 紫金牛' in China and is used as a drug ingredient there (figure 9). ${ }^{83}$ The following chapter outlines the history of the Ardisia species in China, and compares the species to the môgtan.

\section{Comparison between the môgtan and Ardisia species}

As shown in above, Su Jing et al. mentioned 'bailiangjin 百兩金' as an synonym for 'môgtan' in Xinxiu bencao, but in the Song dynasty, Su Song et al. separated it from 'mudan' in Tujing bencao. Similarly in Japan, S. Fukane used 'yamatachibana 山橘' as an alias, but later 'yamatachibana' was separated from 'môgtan'. Surprisingly, 'bailiangjin' is now the standard Chinese name of an Ardisia species, Ardisia crispa Thunb. Zijinniu (yamatachibana) and bailiangjin

81 Ibid., pp. 71, 120 (yamatachibana) '山橘・日かげ・山菅など，うつくしげにかざりて， 御文はなし?'Translation by McKinney 2006, p. 105. Yamatachibana is translated as 'wild orange' by McKinney. For convenience, in this paper it has been replaced with the original word, yamatachibana.

82 Shirai 1975 [1932], p. 98a.

83 Jiangsu Xinyi Xueyuan 1977, pp. 2358-60. 

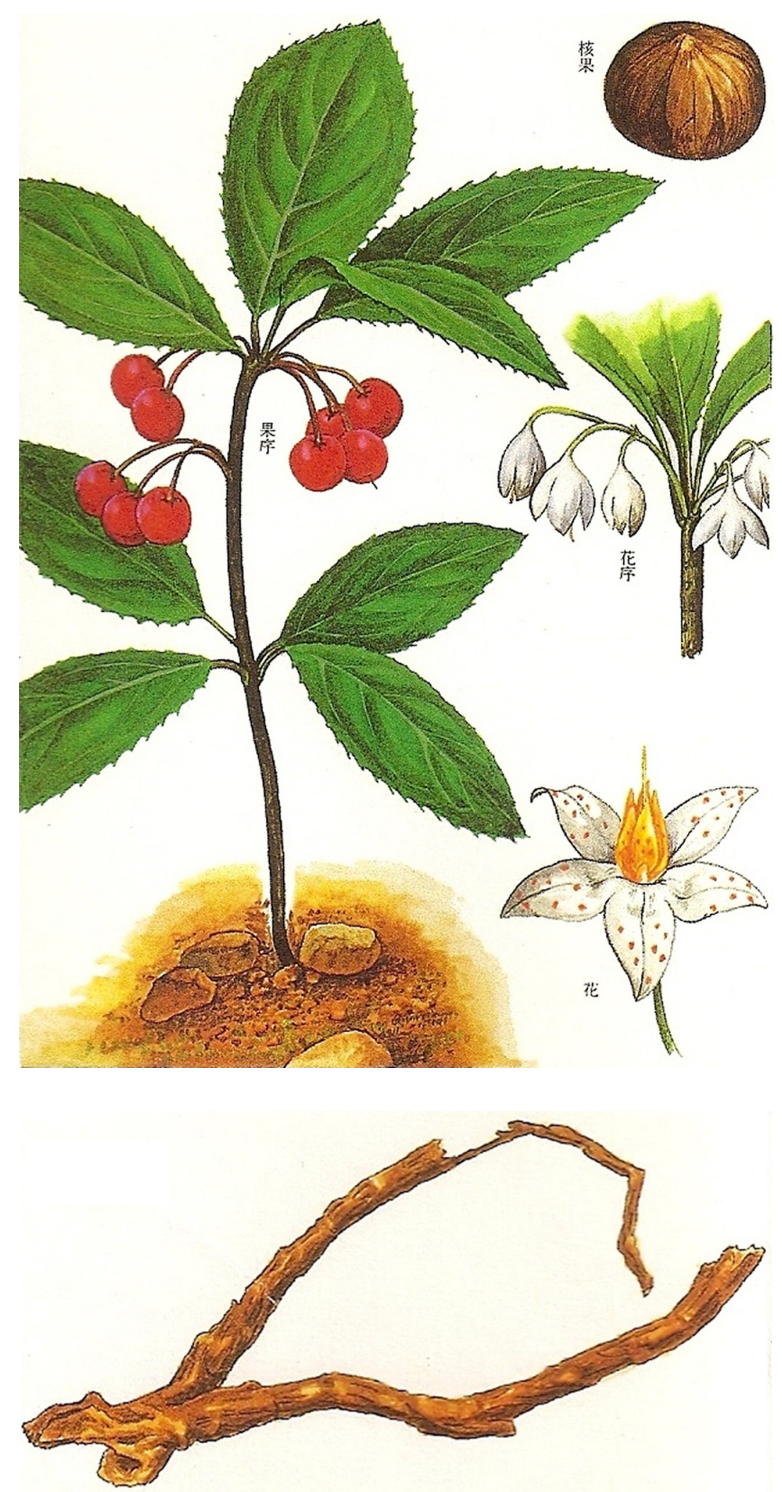

Fig. 8. Yabukôji. ${ }^{84}$ In China, this is called 'zijinniu紫金牛'. It is an evergreen plant with oval leaves like those of citrus.

${ }^{84}$ Okada and Mitsuhashi 1988, p. 383. 


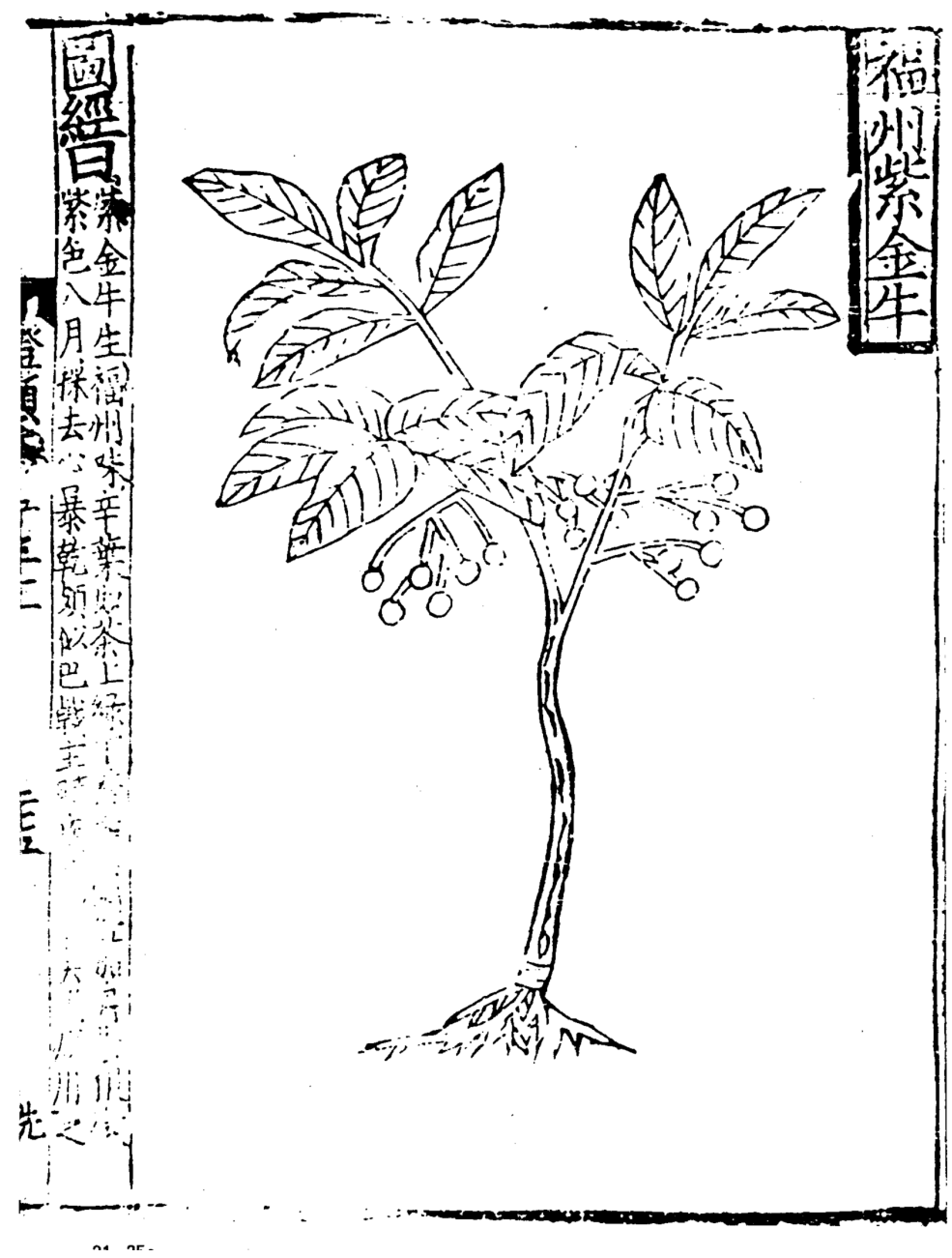

Fig. 9. zijinniu 紫金牛. 85 This illustration was printed in $1211 \mathrm{CE}$, and originated in Tujing bencao 圖經本草 (1061 CE).

first entered bencao books in Tujing bencao. Moreover, the root cortex of the A. crenata Sims (called zhushagen 朱砂根) often gets mingled with that of the tree peony by present-day Chinese drug retailers, because of their similarity of appearance. ${ }^{86}$

${ }^{85}$ Tang Shenwei 1957 [1108], p. 531.

${ }^{86}$ Zeng Jiang 2003, p. 53. 
These three Ardisia species look similar to each other and grow commonly in south China, as Xie Lingyun and Tao Hongjing both mention. These species bloom with white or pinkish-white petals in May and June, and have round, red fruit which ripen between October and December. They also have evergreen leaves. ${ }^{87}$ These features actually closely resemble those, which are shown in table 1 (above). Furthermore, the miao 苗 of the môgtan resembles that of the yangtao 羊桃. The môgtan would seem, thus, to be a creeper. Of the three species, only $A$. japonica is distinguished by its creeper-like shape.

A. japonica grow in dark, damp places such as in bamboo forests or the thick forests of the Shaanxi province and the south of the Yangtze River. ${ }^{88}$ Wild tree peonies are not found south of the Yangtze (except Anhui province), because they grow badly in moist soil and such hot conditions. According to Mingyi bielu 名醫別錄 and Xinxiu bencao, the môgtan was produced in Bajun 巴郡, Hanzhong 漢中 and Jiannan 劍南. In fact, wild tree peonies, as well as $A$. japonica, can grow in these areas. Distribution overlaps such as these played a role in creating inconsistencies of definition not recognised by former investigators.

\section{Etymology of the name môgtan}

Li Shizhen 李時珍 (1518-1593 CE) thought 'tan (dan)', which refers to cinnabar, implied 'red', because the red coloured [either roots or flowers] tree peonies were more valued than those of other colours. 'Môg $(m u)$ ', which refers to the male element, indicates that the tree peony has sprouts to propagate itself despite producing seeds. ${ }^{89}$ In fact, the etymology can be explained more simply now that we know that môgtan was originally the name of Ardisia. In Tujing bencao, zijinniu is described in the following manner: 'the fruits are round and as red as cinnabar. ${ }^{90}$ In addition, colours are generally

${ }^{87}$ Chen Jie 1979, pp. 34-79.

88 I bid. p. 90. '小灌木或亞灌木, 近蔓生, 㘉甸生根的根莖; 直立荎長大 30 厘米, 稀達 40 厘米, 不分枝, 幼時被細微柔毛, 以后無毛... 花瓣粉紅色或白色, 廣卵形, 長 4-5 毫米, 無毛, 密腺點... 花期 5-6 月, 果期 11-12 月, 有時 5-6 月仍有果. 產陝西及長江流域以南各省 區, 海南島未發現, 習見於海拔約 1200 米以下的山間林下或竹林下, 陰濕的地方. 朝鮮, 日本 均有.' According to Okada and Mitsuhashi 1988 (p. 383), it blooms between July and August in Japan.

${ }^{89}$ Li Shizhen 1982 [1596], p. 852 (juan 14). “牡丹以色丹者為上, 雖結子而根上生苗, 故謂 之牡丹.' Besides, Zheng Xuan 鄭玄 remarked that muju 牡蘜 is a non-flowering kind of $j u$ (牡蘜, 蘜不華者) in Zhouli Zhu 周禮注 (Ruan Yuan 1980 [1816], p. 889).

90 Tang Shenwei 1992 [1108] vol. 5: 397; Tang Shenwei 1970 [1108], p. 594; Tang Shenwei 1957 [1108], p. 531. ‘紫金牛. 生福州. 味辛. 葉如茶, 上綠下紫. 實暑紅, 如丹朱. 根微紫色. 八 月採, 去心, 暴乾. 頗似巴戟[天]. 主時疾, 隔氣, 去風痰用之.' Su Song et al. indicated that zijingniu looks very similar to baji(tian). 
pre-modifiers in Chinese names of drug ingredients. Most of these names, for example danshen 丹參, qinghao 青蒿, huangqin 黃芩, follow this regulation, though dahuang 大黃 is a notable exception. Therefore, the character 'dan 丹' in the name môgtan may not only refer to its colour but also connect to danyao 丹藥 (cinnabar pills). Indeed, its small round fruits are associated with wanyao 丸藥, pills.

Both $m u$ 牡 (male) and $m u$ 木 (wood) are now pronounced with the same sound ' $m u$ ' but with different tones, and it is also presumed that both initial consonants were also pronounced ' $m$ ' in the past. However, based on Guangyun 廣韻 (1008 CE), ' $m u$ ' (male) was pronounced with shangsheng 上聲, but ' $m u$ ' (wood) was pronounced with rusheng 入聲 during the Sui and Tang dynasty. ${ }^{91}$ ' $M u$ ' (male) was pronounced as 'mau' (Karlgren) or ' muwX' (Baxter, ' $X$ ' represents Shangsheng), and ' $m u$ ' (male) was pronounced as 'muk' (Karlgren) or 'muwk' (Baxter). ${ }^{92}$ Both sounds were clearly distinguished by the differences on the post-codas; accordingly the sounds were hardly interchangable with each other during Sui-Tang dynasties.

Yet, the both sounds in the old Chinese of the Han and the earlier dynasties are presumed as: '* $m o \hat{g}$ ' (male) and '* $m u k$ ' (wood) by Karlgren; and '* $m(r) u$ ?" and '* $m o k$ ' by Baxter. ${ }^{92}$ The sound of ' $m u$ ' (male) was, therefore, relatively closer to ' $m u$ ' (wood) in the Han dynasty. Besides, Mayanagi has concluded that 'mugui'木桂 in Eryazhu 爾雅注 and 'mugui' 牡桂 in Shennong bencao jing 神農本草經 are the same. ${ }^{93}$ This is an example that ' $m u$ ' (wood) might be occasionally interchanged with ' $m u$ ' (male) in the Han dynasty. Môgtan, therefore, probably translates as 'woody cinnabar pills'.

\section{Conclusion}

The above discussion has traced the story of the mogtan and determined that it was called 'bailiangjin' in the Chutang era in China and 'yama-tachibana' in early Japan, and that both these aliases in fact referred to the Ardisia species. The description of the môgtan in the Xinxiu bencao also matches the Ardisia. The bajitian, mentioned by Tao Hongjing as a plant resembling the môgtan, looks similar to the Ardisia japonica as well. On the other hand, the counterfeit

${ }^{1}$ Chen Pengnian et al. 1976 [1008], pp. 325, 452. Shangsheng (Shăngshēng) literally means "raising tone', but this is the origin of the third tone in contemporary Mandarin Chinese.

92 Baxter demonstrated the phonetic similarity of '- $k$ ' (a kind of Rushing 入聲) and '-?' (a post-coda) (Baxter 1992, pp. 323-24).

93 Mayanagi 1995. 

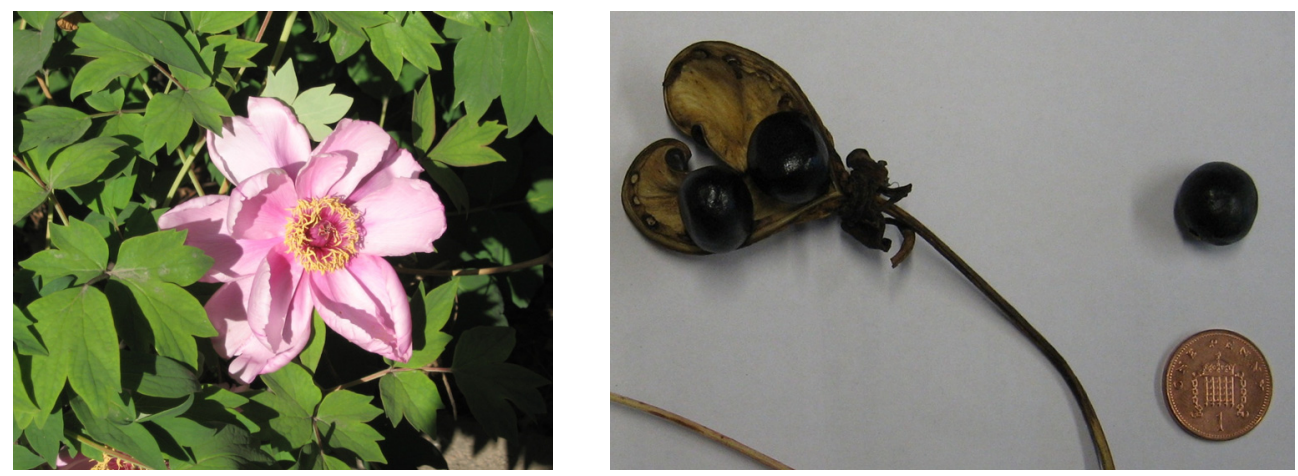

Fig. 10. left: Paeonia suffruticosa (at Fu Wangfu 孚王府, or the site of the Institute for the History of Natural Science, Beijing in April 2009); right: Seeds of P. suffruticosa (November 2007).
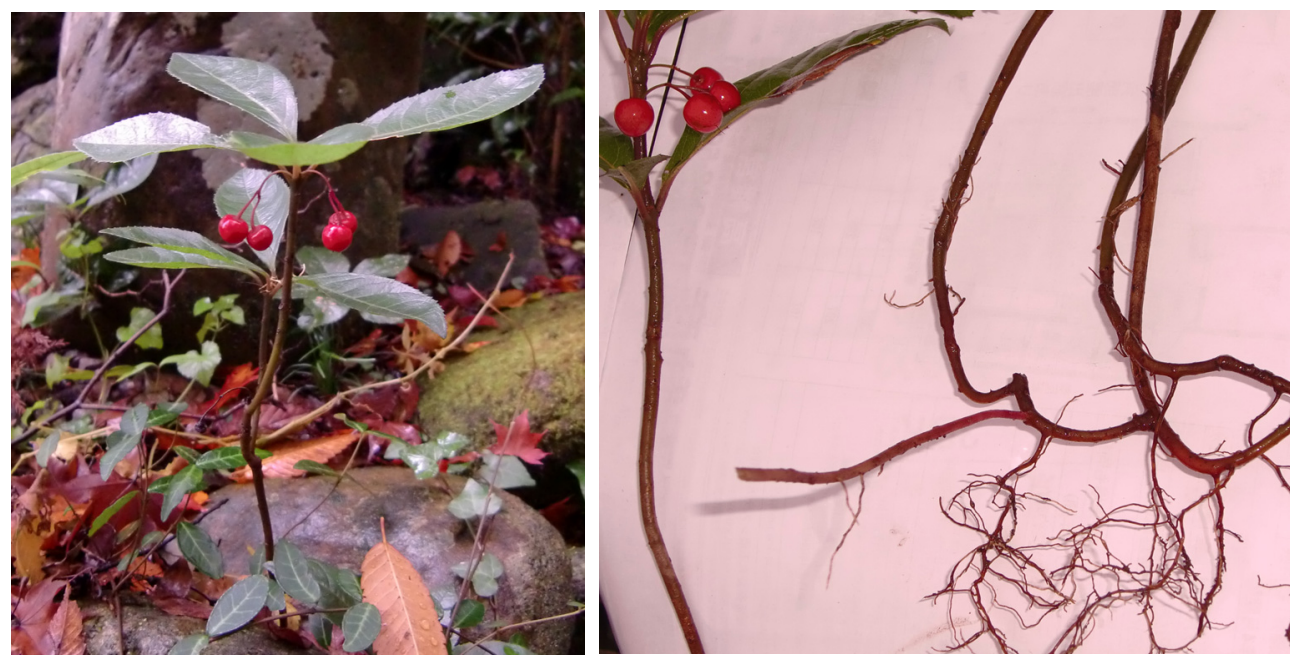

Fig. 11. left: Ardisia japonica (Ome 青梅, Tokyo in November 2009); right: rootstock of A. japonica. 
môgtan mentioned in our discussion probably refers to the tree peony, the evidence being the tell-tale smell of the tree peony's root cortex.

Therefore, it can be concluded that 'môgtan' from the Southern dynasties to the Chutang era referred to a plant different from the tree peony, which most likely is a member of Ardisia species, specifically the A. Japonica, even though the tree peony came to be referred to as môgtan around the Chang'an region. Unfortunately, too few historical materials remain from the Han 漢 and Wei Jin 魏晉 dynasties (and maybe the Northern dynasties, or Bei chao 北朝) to demonstrate which plant was used in medicine.

The turning point for the Ardisia and the tree peony was during the Shengtang era, when the tree peony was first praised in the inner court, though people of the court did not call it 'mu-shaoyao'. In $755 \mathrm{CE}$, the Chinese emperor Xuanzong faced the rebellion and withdrew to Shu 蜀 (present-day Sichuan province) with his family and entourage. The rebellious troops, however, did not reach Chang'an. In the spring of following year, probably for the first time, capital citizens were able to see these flowers in the private gardens of high officials and the emperor. They also began to praise the tree peony, but used its vernacular name, 'môgtan'.

Nakao and Kimura thought the tree peony was being cultivated before the time of the Tang dynasty, and that the counterfeit môgtan actually referred to cultivated tree peonies. However, that interpretation conflicts with Xinxiu bencao. In Xinxiu bencao, the genuine môgtan was called 'wu-môgtan' in Chang'an, although wild tree peonies grow near Chang'an and can be easily supplied to Chang'an. Again, if we consider the môgtan mentioned in the Izumonokuni fudoki, its similarities with the bajitian, and what is known of the mogtan's distribution and growing environments, it is entirely plausible that the genuine môgtan described in these references does not, in fact, refer to the tree peony. The most likely species that could have been meant by 'genuine môgtan' is the Ardisia.

The tree peony does possess proven medical benefits such as anti-inflammatory, muscle relaxant and analgesic actions. Ancient physicians accepted without question the medical benefits of the môgtan, so they may not have realized the difference. Chinese physicians have accumulated clinical experience of using tree peonies medicinally over twelve centuries. This paper, therefore, does not recommend that Ardisia replace tree peonies in all early prescriptions involving mudan (môgtan), but it is hoped that its findings will stimulate further interest in the Ardisia species, and their as yet unexplored potential medical benefits. 


\section{Acknowledgement}

This work was supported by an Andrew W. Mellon Foundation Research Fellowship and the Chinese Academy of Sciences scholarship. I would also like to express my sincere gratitude to my advisor Professor Luo Guihuan, Professor Makoto Mayanagi, Dr Vivienne Lo and Mr. John Moffett.

\section{References}

Andrews, Henry C. 1804, The Botanist's Repository 6, London: self-published.

Asahina, Yasuhiko 朝比奈泰彥 (ed) 1995, Shôsôin yakubutsu 正倉院藥物 (Shosoin Medicines), Osaka: Shokubutsu bunken kanôkai 植物文獻刊行會.

Arichi, Shigeru, Michinori Kubo, Hideaki Matsuda, Tadao Tani, Tadahito Tani, Kayoko Tsunaga, Masayuki Yoshikawa and Isao Kitagawa 1979, 'Studies on MOUTAN CORTEX (III) On Anti-inflammatory Activities (Part 1)', Shoyakugaku zasshi 生藥學雜誌, 33(3): pp. 178-84 (in Japanese).

Baxter, William H. 1992, A Handbook of Old Chinese Phonology, Berlin: Mouton de Gruyter.

Chen Jie 陳介 1979, Zhongguo zhiwuzhi 中國植物志 (Flora of China) 58, Beijing: Kexue chubanshe 科學出版社.

Chen Pengnian 陳彭年 et al. 1976 [1008], Jiaozheng Songben Guangyun 校正宋本廣韻, Taibei: Yiwen yinshu guan 藝文印書館.

Chen Ranglian 陳讓廉 2004, Tongling mudan 銅陵牡丹 (Tree peonies in Tongling), Beijing: China Forestry publishing house.

Chen Tiemin 陳鐵民 (ed) 1997, Wangwei ji jiaozhu 王維集校注, Beijing: Zhonghua shuju 中華書局.

Chen Xueliang 陳雪亮 (ed) 2006, Tang Wudai Liangsong renwu minghua 唐五代兩宋人物名畫, Hangzhou: Xiling chubanshe 西泠印社出版社.

Cui Bao 崔豹 1998 [fl. 290-306], Gujin zhu 古今注, revised by Jiao Jie 焦傑, Shenyang: Liaoning jiaoyu chubanshe 遼寧教育出版社.

Dai Songcheng 戴松成 et al. (eds) 2008, Guohua mudan dang'an 國花牡丹檔案 (Documentation of the national flower, the tree peony), Kaifeng: Henan daxue chubanshe 河南大學出版 社.

Duan Chengshi 段成式 1981 [c. 860], Youyang zazu 酉陽雜㸖, Beijing: Zhonghua shuju.

Fan Shu 范摅 1957, Yunxi Youyi 雲溪友議, Shanghai: Gudian wenxue chubanshe 古典文學出 版社.

Fujiwara, Tokihira 藤原時平 et al. 1985 [927], Engi shiki 延喜式, Kokushi taikei 國史大系, Tokyo: Yoshikawa kôbunkan 吉川弘文館.

Fukane, Sukehito 深江輔仁 1928 [918], Honzô wamyô 本草和名 (上冊 Jôsatsu), in Atsuo Masamune 正宗敦夫 (ed) Nihon koten zenshû kankôkai 日本古典全集刊行會.

Furuta, Shin'iChi 古田眞一 2003, 'Court Ladies Punning on Flowers in the Liaoning Museum (Attributed to Zhou Fang in Tang dynasty)', Geijutsu ronkyu 藝術論究 (Studies of Aesthetics, Art Criticism and Art History), 30: 13-39 (in Japanese).

Gangsu Bowuguan 甘肅博物館 and Wuxian wenhuaguan 武威縣文化館 (eds) 1975, Wuwei handai yijian 武威漢代醫簡 (Wuwei Medical Bamboo Slips of the Han Dynasty), Beijing: Wenwu chubanshe 文物出版社. 
Gotô, Zôshirô 後藤藏四郎 1926, Izumonokuni fudoki kôshô 出雲國風土記考證, Tokyo: Ôka shoten 大崗書店.

Guo Shaolin 郭紹林 1997, 'Guanyu Luoyang lailide liangze cuowufa ‘關于洛陽牡丹來歷的兩 則錯誤法 (Two wrong conceptions concerning the origin of mudan)', Luoyang daxue xuebao 洛陽大學學報 (Journal of Luoyang University), 12(1): 6-9.

Guo Xiumei 郭秀梅 and Kenkichi Okada 崗田研吉 1999, Riben yijia Jinkui Yaolüe zhujie jiyao 日本醫家金贾要略注解輯要, Beijing: Xueyuan chubanshe 學苑出版社.

Halda, Josef J. and Jaems Waddick 2004, The Genus Paeonia, Porland: Timber Press.

Hashimoto, Ryôji 橋本亮二 1986, Botan Hyakka Shû 牡丹百花集, Tokyo: Seibun dô 誠文堂.

Hong Tao 洪濤, Zhang Jiaxun 張家勳, Li Jiajue 李嘉珏, Zhao Wenzhong 趙文忠, Li Mingduan 李明瑞 1992, 'Study on the Chinese Wild Woody Peonies II. New Taxa of Paeonia L. Sect. Moutan' Zhiwu yanjiu 植物研究 (Bulletin of botanical research, Harbin) 12 (3): pp. 223-234 (in Chinese).

Hong Tao and Gian L. Osti 1994, Zhiwu yanjiu 植物研究 14(3): pp. 237-240 (in Chinese).

Hong Tao and Dai Zhenlun 戴振倫 1997, Zhiwu yanjiu 植物研究 17(1): 1-5 (in Chinese).

Huang Xiufu 黄休復 2006 [c. 1018], 'Maoting kehua 茅亭客話’, in Quan Song biji 全宋筆記, Zhengzhou 鄭州: Daxiang chubanshe 大象出版社.

Ikeda, Kikan 池田龜鑒 1962, Makurano sôshi $i$ 枕草子, Tokyo: Iwanami shoten.

Ishida, Mikinosuke 石田幹之助 1967 [1941], Chôanno haru 長安の春 (Chang'an in spring), Tokyo: Heibonsha.

Jiangsu meishu chubanshe 江蘇美術出版社 (ed.) 2000a, Gu kaizhi xiao yi huihua changjuan sikuan changjuan zhi yi 顧愷之蕭繹繪畫長卷四款 長卷之一, Nanjing: Jiangsu meishu chubanshe.

Jiangsu meishu chubanshe 江蘇美術出版社 (ed) 2000b, Zhongguo lidai renwuhua jingdian 中國 歷代人物畫經典, Nanjing: Jiangsu meishu chubanshe 江蘇美術出版社.

Jiangsu xinyi xueyuan 江蘇新醫學院 1997, Zhongyao dacidian 中藥大辭典 (Encyclopedia of Chinese materia medica), Shanghai: Shanghai kexuejishu chubanshe 上海科學技術出版社.

Kakimoto, Susumu 柿本獎 1966, Kagerô Nikki zechîshaku 蜻蛉日記全注釋, Tokyo: Kadokawa shoten.

Kano, Y., T. Kubo, N. Yoshino 2003, 'A Study of Pi-ya 埤雅, Part V, Plants (1)' Bulletin of the College of Humanities Ibaraki University 39: 138-115 (in Japanese).

Kariya, Ekisai 狩谷棭齋 1981 [1827], 'Senchû wamyô ruijushô 箋注倭名類聚抄’ in Kyôdaibungakubu Kokugogaku kokubungaku kenkyûshitsu 京大文學部國語學國文學研究室 (ed) Shohonshîsei wamyô ruijushô 諸本集成倭名類聚抄, Kyoto: Rinsen book.

Karlgren, Berhard 1972 [1957], Grammata Serica Recensa, Stockholm: Östasiatiska Museet.

Katô, Yoshinari 加藤義成 1962, Izumono kuni fudoki sankyû 出雲國風土記參究, Tokyo: Hara shôbo 原書房.

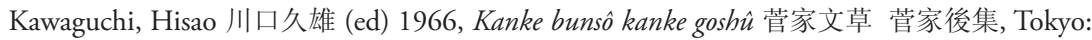
Iwanami shoten

Kubo, Michinori, Tadao Tani, Hiroshi Kosoto, Yoshiyuki Kimura and Shigeru Arichi 1979, 'Studies on MOUTAN CORTEX (I) Historical Analysis', Shoyakugaku zasshi 生藥學雜誌, 33(3):155-65 (in Japanese).

Li Chuo 李綽 1936 [c. Wangtang], Shangshu gushi 尚書故實, Shanghai: Shangwu yinshu guan 商務印書館.

Li Fang 李昉 et al. (eds) 1960 [984], Taiping yulan 太平御覧, Beijing: Zhonghua shuju 中華書局.

Li Jun 李㴭 1991 [c. 800], Songchuang zalu 松牕雜錄 in Wang Yunwu 王雲五 (ed), Congshu jicheng chubian 叢書集成初編 2743, Beijing: Zhonghua shuju 中華書局.

Li Shizhen 李時珍 1982 [1596], Bencao gangmu 本草網目, Beijing: Renmin weisheng chubanshe 人民衛生出版社. 
Li Shutong 李樹桐 1972 [1969], 'Tangren xiai mudankao 唐人喜愛牡丹考 (Research on the peony vogue in the Tang)', in Tangshi xinlun 唐史新論, Taibei: Taiwan Zhonghua shuju 臺灣 中華書局.

Li Zhao 李肇 1979, Tangguoshibu 唐國史補, Shanghai: Shanghai guji chubanshe 上海古籍出版社.

Liu Xu 劉昫 et al. 1975 [945], Jiu Tang shu 舊唐書, Beijing: Zhonghua shuju.

Ma Jixing 馬繼興 1995, Shennong bencaojing ji 神農本草經輯, Beijing: Renmin weisheng chubanshe.

Mayanagi, Makoto 真柳誠 1995, 'The names of drugs in the cassia-bark family in China prior to the 11 th century', Yakugaku zasshi 藥史學雜誌 (The Japanese Journal for History of Pharmacy), 30(2): 96-115 (in Japanese).

McCullough, Helen C. 1985, Kokin wakashû, California: Stanford University Press.

McKinney, Meredith 2006, The Pillow Book, London, UK: Penguin Books.

Meng Qingyuan 孟慶元 1980, Zhongguo gudanshi changshi (Zhuanti Fence) 中國古代史常識 (專題分冊), Beijing: Zhongguo qingnian chubanshe 中國青年出版社.

Mizukami, Shizuo 水上靜夫 1977, Chîgoku kodai no shokubutsu no kenkyû 中國古代の植物學 の研究 (A Study of botany in ancient China), Tokyo: Kadokawa shoten.

Nakao, Manzô 中尾萬三 and Kôichi Kimura 木村康一 1930, 'Photographic catalogue of Chinese drugs II', Bulletin of the Shanghai Science Institute, 1(5). (in Japanese)

Needham, Joseph 1986, Science and Civilisation In China vol. 6: 1, Cambridge: Cambridge University Press.

Okada, Minoru 崗田稔 and Hiroshi Mitsuhasi 三橋博 1988, Genshoku makino wakan yakusou zukan 原色牧野和漢藥草圖鑒 (Illustrated medicinal plants of the world), Tokyo: Hokuryukan 北隆館.

Osti, G. L. 1999, The book of tree peonies, Turin: Umberto Allemandi \& C.

Ouyang xiu 歐陽修 2001 [c. 1034], Luoyang mudanji 洛陽生丹記, in Ouyang Xiu qianji 歐陽 修全集, Zhonghua shuju (3), Beijing: Zhonghua shuju.

Ouyang Xiu et al. 1995 [1060], Xin Tang Shu 新唐書, Beijing: Zhonghua shuju.

Ou Yangxun 歐陽詢 1999 [624], Yiwen Leiju 藝文類聚, revised by Wang Shaoying 汪紹盔, Shanghai: Shanghai guji chubanshe.

Pang Dingqiu 彭定求 1960 [1706], Quan Tang Shi 全唐詩, Beijing: Zhonghua shuju.

Ruan Yuan 阮元 (ed) 1980 [1816], Shisan jing zhushu 十三經注疏 (Thirteen Classics with Annotations) Beijing: Zhonghua shuju.

Satake, Akihiro 佐竹昭廣, Hideo Yamada 山田英雄, Rikio Kudô 工藤力男, Masao Ôtani 大谷 雅夫, Yoshiyuki Yamazaki 山崎福之 1999, Manyôshîu 萬葉集 (1), Tokyo: Iwanami shoten.

Shanxisheng Bowuguan 陝西省博物館 (ed.) 1981, Yongtai gongzhu mu shiguixianhua 永泰公主 石楟線畫, Xi'an: Shanxi renmin meishu chubanshe 陝西人民美術出版社.

Shang Zhijun 2005, Wushi bencao jing 吳氏本草經, Beijing: Zhongyi guji chubanshe.

Shen Congwen 沈從文 1981, Zhongguo lidai fushi yanjiu 中國歷代服飾研究, Hongkong: Shangwu yinshu guan 商務印書館.

Shi Weile 史為樂 et al. (eds.) 2005, Zhongguo lishi diming dacidian 中國歷史地名大辭典 (Dictionary of Chinese Historical Toponyms), Beijing: Zhongguo shehui kexue chubanshe.

Shirai, Mitsutarô 白井光太郎 (ed) 1975 [1932], Yamato honzô 大和本草 (Japanese herbal), Tokyo: Ariake shobô 有明書房.

Stern, F. Claude 1946, A study of the Genus Paeony, London.

Smrž, Oskar 1925, Pivoňky a jak se pěstuji (Peonies and how to grow them), Pardibice: Př́itel Zahrad.

Tanaka, Yûjirô 田中勇次郎 1962, Bunbô seigan 文房清玩 vol. 3, Tokyo: Nigensha 二玄社.

Tang Shenwei 唐慎微 1992 [1108], Jingshi zhenglei beiyong bencao 經史證類備急本草 (Tôyô Yigaku Zenpon Sossho 東洋醫學善本叢書 vol. 30-34), revised by Ai Sheng 艾晟 et al. in 1108 and printed by Liu Jia 劉甲 in 1211, Osaka: Oriento shuppansha オリエント出版社 (facsimile). 
Tang Shenwen 唐慎微 1970 [1108], Jingshi zhenghe daguan bencao 經史證類大觀本草, revised by Ai Sheng 艾晟 et al. in 1108 and printed by Ke Fengshi 柯逢時 in 1904, Tokyo: Hirokawa shoten 廣川書店 (facsimile).

Tang Shenwen 唐慎微 1957 [1108], Chongxiu zhenghe jingshi zhenglei bencao 重修政和經史證 類備用本草, revised by Cao Xiaozhong 曹孝忠 et al. in 1116 and Zhang Cunhui 張存惠 in 1249, Beijing: Renmin weisheng chubanshe (facsimile).

Tôdô, Akiyasu 藤堂明保 1978, Gakken Kanwa Daijiten 學研漢和大字典, Tokyo: Gakken.

Unschuld, Paul U. 1985, Medicine in China: A History of Ideas, Berkeley: University of California Press.

Wang Niansun 王念孫 2004 [1796], Guangya Shuzheng 廣雅疏證, Beijing: Zhonghua shudian.

Wang Fu 王傅 1955 [c. 10c], Tang Huiyao 唐會要, Shanghai: Zhonghua shuju.

Watson, Burton 2000, PO CHU-I: selected poems, New York: Columbia University Press.

Yao Jiheng 姚際恆 1958 [c. 1709], Shi jing tonglun 詩經通論, Beijing: Zhonghua Shuju.

Yong Rong 永瑢 et al. 1986, 'Siku Quanshu Zongmu Tiyao 四庫全書總目提要', in Wenjinge siku quanshu 文津閣四庫全書 3, Taibei: Taiwai shangwu yinshuguan 臺灣商務印書館.

Yu Jiaxi 余嘉錫 1958, Siku quanshu tiyao bianzheng 四庫全書提要辨証, Beijing: Kexue chubanshe 科學出版社, pp. 853-863.

Yuanfang 巢元方 et al. 1996 [610], Zhubing yuanhou lun jiaozhu 諸病源候論校注, revised by Ding Guangdi 丁光迪, Beijing: Renmin weisheng chubanshe.

Zeng Jiang 曾江 2003, 'Mudanpi yu Zhushagen, Baixianpi de jianbie bijiao 牡丹皮與朱砂根, 白鮮皮的鑒別比較 (Comparative identification between Moutan cortex, Radix Ardisiae Crenata and Dictamni Cortex)', Hufbei zhongyi zazhi 湖北中醫雜志 25(11): 53.

Zhang Anzu 張安祖 1995, 'Lun Bai Juyi jian Xu Ning Qu Zhang Gu 論白居易薦徐凝屈張祜 (Study on Bai Juyi, commending Xu Ning and rejecting Zhang Hu )', Beifang luncong 北方論叢 133: 77-81.

Zhang Yanyuan 張彥遠 1963, Lidai Minghua Ji 歷代名畫記, Beijing: Xinhua shudian.

Zheng Qiao 1987 [1161], Tong Zhi 通志, Beijing: Zhonghua shuju.

Zhu Jincheng 朱金城 (ed) 1988, Baijuyi Ji Jianjiao 白居易集箋校, Shanghai: Shanghai guji chubanshe. 